\title{
APONTAMENTOS SOBRE A EVOLUÇÃO DOS COMPONENTES ESTRUTURAIS DO “PRESSUPOSTO DE FATO” (FATO GERADOR OU HIPÓTESE DE INCIDÊNCIA) NO DIREITO TRIBUTÁRIO.
}

\author{
Jeferson Teodorovicz ${ }^{1}$
}

\section{RESUMO}

O presente estudo realiza análise panorâmica sobre a evolução doutrinária relativa ao gradual reconhecimento da estrutura da norma tributária, enfocando seus componentes (elementos, aspectos ou critérios) através de uma estratégia metodológica histórico-evolutiva, a partir das primeiras composições teóricas ligadas ao Tatbestand (pressupposto di fatto ou fattispecie). Assim, inicia-se a presente investigação com análise dos antecedentes teóricos, especialmente no campo da Economia Pública (Ciência das Finanças), no Direito Penal e no Direito Administrativo sobre o tema. Depois, percorre-se a polêmica da identificação dos critérios através da noção de causa, elemento ou pressuposto da obrigação tributária, tema recorrente nas primeiras décadas do século $\mathrm{XX}$ na literatura europeia. Ademais, busca-se compreender, sob perspectiva jurídica, as diferentes posições doutrinárias (européias e latino-americanas, especialmente) sobre a estrutura (e respectivos componentes) no período de "glorificação do fato gerador". Após, observando a experiência doutrinária e legislativa antecedente, investiga-se a evolução doutrinária e legislativa brasileira sobre a problemática, que se fortaleceu gradualmente a partir da década de quarenta do século XX, mas que ainda nos dias atuais mantém-se perene.

PALAVRAS-CHAVE: Fato Gerador. Hipótese de Incidência. Regra-Matriz. Norma Tributária. Critérios.

\section{INTRODUÇÃO}

\footnotetext{
${ }^{1}$ Doutor em Direito Econômico e Financeiro pela USP. Mestre em Direito pela PUC-PR. Professor do Programa de Pós-Graduação Stricto Sensu (Mestrado) em Direito da Universidade Católica de Brasília. Professor Substituto de Direito Empresarial, Direito Tributário e Direito Internacional Privado da Universidade Federal do Paraná. Professor de Direito Tributário da Unidombosco e da Uninter. Universidade Católica de Brasília. Universidade Federal do Paraná. Brasil Uninter. Unidombosco ORCID iD: http://lattes.cnpq.br/5360964638266778 Lattes: Jeferson Teodorovicz (0000-00031018-6438) E-mail: jeferson.teodorovicz@yahoo.com.br
} 
O presente estudo pretende demonstrar que a gradual identificação de elementos componentes da estrutura do tributo passou por três fases: a) identificação pontual e por vezes desestruturada dos elementos do tributo, no âmbito da Ciência das Finanças; b) identificação dos elementos do pressuposto de fato, considerando-o enquanto elemento da obrigação tributária e, por isso, ligando-o à estrutura fundamental da relação jurídico-tributária obrigacional (seja enquanto pressuposto ou elemento da obrigação); c) a identificação de elementos, aspectos ou critérios a partir de uma visão dogmático-normativa, que, por sua vez, subdividiu-se em dois momentos: c.1.) primeiro momento, ligando os elementos ao pressuposto (hipótese) ou antecedente normativo, concedendo pouco ou nenhum espaço ao consequente (relação tributária); c.2) segundo momento, distribuindo os elementos, aspectos ou critérios de forma mais racional entre o antecedente normativo e o consequente normativo.

Buscar-se-á, assim, revisitar aspectos pontuais desse processo histórico-doutrinário, principiando pelos esforços da literatura tributária estrangeira, também observável em estudos antecedentes no âmbito do Direito Público e da Ciência das Finanças, passando pelo tratamento do Tatbestand na legislação e literatura estrangeiras, para então discorrer sobre os esforços na identificação dos elementos estruturais da norma tributária na literatura nacional.

\section{ANTECEDENTES FINANCISTAS E PUBLICISTAS À DELIMITAÇÃO DOS ELEMENTOS DO TRIBUTO}

Primeiramente, sem ignorar a essencial construção da teoria do tipo na Ciência do Direito Penal, com graduais reflexos na teoria do Tatbestand tributário (SCHOUERI, 2003, p.128-130; ZILVETI, 2009, p.124 e ss; DERZI, 1988, p.43-45), deve-se reconhecer que a preocupação para a identificação dos componentes estruturais da norma tributária encontra efetivos antecedentes na Ciência das Finanças, sobretudo durante o século XIX e o início do século XX. Nesses estudos de natureza econômica era comum a preocupação com a identificação do objeto do imposto, do assento do imposto, da incidência, e era comum a preocupação para melhor visualização do sujeito que deveria pagar o tributo, bem como da medida do imposto (base de cálculo) e própria taxa (alíquota) aplicável, visando também facilitar a determinação do montante tributável (BALEEIRO, s/d, p.37; MACHADO, 1974, p.vii-viii; WAGNER, 1909, p. 111-119; SELIGMAN, 1914, p.120-144).

Em praticamente todos os estudos financistas era possível visualizar esses elementos. Consequentemente, a literatura do Direito Público Europeu (Administrativo e Financeiro), entre o século XIX e início do século XX, logo absorveu essa mesma preocupação, conforme se pode 
observar em Mayer (1950, p. 189 e ss), Fleiner (1933, p.252-266) e Myrbach-Rheinfeld (1910, p. 132 e ss).

Ainda, a literatura financista brasileira no século XIX e início do século XX também registrou semelhante característica, conforme se observa em Dídimo Veiga (1927, p.172), Viveiros de Castro (CASTRO, 1910, p. 95-205) e Rui Barbosa (1949, p.52 e ss), praticamente reproduzindo a identificação desses elementos na estrutura do tributo, e de alguns conceitos financistas que influenciariam a literatura tributária brasileira, quais sejam: sujeito e objeto da tributação ou objeto do imposto, assento do imposto, taxa, medida do tributo e incidência.

Porém, a preocupação da literatura tributária (e já não apenas sob a perspectiva do Direito Administrativo ou da Ciência das Finanças) sobre o problema da identificação dos elementos do tributo (agora já ligada à ideia de suposto de fato ou pressuposto de fato) iniciou-se efetivamente com a previsão expressa do Tatbestand no Reichsabgabenordnung - Código Tributário Alemão, de 1919 (1941, p. 09 e ss; DINIZ, 1965, p. 221-233), graças a Enno Becker (BECKER; RIEWALD; KOCH, 1963, p. 11), juiz fiscal alemão e grande responsável pela criação da Ordenação Tributária do Reich.

Logo no início do Código Tributário Alemão já era possível visualizar a importância do Tatbestand ("suposto de fato" ou "pressuposto de fato"), pois no $§ 1^{\circ}$ item 1) foi prevista a definição de impostos (Steuern) como prestações em dinheiro que não representam contraprestação por prestação particular, por sua vez impostas por uma comunidade de direito público para a percepção de receitas, determinando que o imposto seria devido de todos aqueles “(...) em relação aos quais ocorre um estado de fato ao qual a lei liga a obrigação da prestação" (bei denen der Tatbestand zutrifft, an den das Gesetz die Leistungspflicht knüpft ) (1941, p. 09 e ss; BECKER; RIEWALD; KOCH, 1963, p. 11).

O Código Tributário Alemão, ao mencionar “der Tatbestand zutrifft”, enquanto situação de fato ou estado de fato ligado à obrigação, impulsiona a literatura tributária europeia, que imediatamente emergente desse período passa a preocupar-se com a delimitação do pressuposto de fato (suposto de fato, suposto fático) que, ocorrido no mundo real, dá surgimento à obrigação de pagar o tributo. Logo, para a verificação dessa ocorrência é presumida a identificação dos elementos que compõe esse suposto ou pressuposto.

Assim, os elementos do tributo passam a ser identificáveis aos elementos do pressuposto de fato (e à própria obrigação tributária).

Do ponto de vista terminológico, contudo, a preocupação preliminar a ser enfrentada pela literatura a partir de sua previsão legislativa inaugural no Código Tributário Alemão, em 1919, foi a delimitação do pressuposto (e, nesse contexto, de seus elementos) e sua distinção terminológica. 
Evidentemente, várias propostas terminológicas para delimitar a expressão "Tatbestand" surgiram na literatura europeia. Ernst Blumentein (1954, p. 111), por exemplo, usava a expressão "Steuerobjek" como sinônimo de Tatbestand.

Evidentemente, Blumenstein inspirava-se na experiência financista do século XIX, que comumente tratava do "objeto do imposto" enquanto referente à matéria (econômica) sobre o qual recai a tributação. Assim, a literatura germânica, com fidelidade ao Código Tributário Alemão, passou a utilizar a expressão "Tatbestand", que significaria "suposto de fato", "suposto fático" ou "pressuposto de fato".

Hensel (1956, pp.50;85), nesse sentido, foi um dos principais responsáveis pela delimitação e difusão do conceito, especialmente difundido na literatura tributária italiana, cuja expressão passou a significar "pressupposto di fatto".

$\mathrm{Na}$ Itália, porém, outras expressões foram utilizadas, a exemplo de fattispecie, por influência de Emilio Betti, conforme informa Micheli (1954, pp.324-325), que usou a expressão com originalidade e que depois serviria também para designar o pressupposto di fatto. Outras expressões também apareceram como atto generattore ou fatto generattore (BERLIRI, 1952, p.233-264), ou mesmo situação-base (ALLORIO, 1963, p. 65). Mas prevaleceram o pressupposto di fatto e a fattispecie como sinônimos de Tatbestand, conforme se observa em Giannini (p.82), Vanoni (1962, p. 293-297), Puglièse (1939, pp.115;135) e Tesoro (1938, p.144-173).

Porém, independente das expressões utilizadas, o Tatbestand (pressupposto di fatto ou fattispecie) passou a significar, na contribuição de Hensel:

(...) o complexo dos pressupostos abstratos, contidos na norma de direito tributário material, pela qual a concreta existência (realização do pressuposto de fato), deriva determinada consequência jurídica. A fattispecie do imposto (Tatbestand) é, por assim dizer, a imagem abstrata do concreto estado das coisas (HENSEL, 1956, p. 111).

$\mathrm{Na}$ América Latina, contudo, assim como na realidade brasileira, prevaleceram as expressões fato imponível ou "hecho imponible" (JARACH, p.93 e ss) e fâit genératour ou "fato gerador" (JÈZE, 1945, p.50-63), ambos com o mesmo significado de pressuposto de fato (Tatbestand), isto é o pressuposto de fato necessário e previsto em lei que, uma vez ocorrido na realidade fática, autoriza a incidência da obrigação tributária.

Especialmente na literatura latino-americana prevaleceu, por influência de Jarach, o "fato imponível" (hecho imponible), A mesma tendência foi seguida por Héctor Villegas (1980, pp.100101), Giuliani Fonrouge (1981, p.87), Bielsa (1951, pp.131-133) e Sainz de Bujanda (1966, p. 285 e ss), todos seguindo a tradição de Jarach (2006, p.94-96), ao passo que no Brasil, prevaleceu na 
legislação (e na literatura), a expressão "fato gerador” (fâit genératour), por influência de Gastón Jèze (1945, p. 50 e ss).

No Brasil, a prevalência do uso do fato gerador foi ampla nas décadas de quarenta, cinquenta e sessenta, na doutrina e nos esforços codificadores (1953, 1954 e 1966), levando à inserção do termo no Código Tributário Nacional, além de, hodiernamente, ter previsão expressa em diversos artigos da Constituição Federal.

Assim, o pressuposto de fato seria também o pressuposto para o surgimento da obrigação tributária. Não por outro motivo, passou a ser considerado, pelo menos inicialmente, como elemento ínsito à obrigação tributária ou como pressuposto que autorizaria a criação da obrigação tributária.

Consequentemente, a identificação da estrutura e dos elementos ínsitos ao pressuposto de fato (Tabestand, fattispecie, etc.) seguiu influenciada por essa visão prevalecente na literatura europeia no período entre a Primeira Guerra e a Segunda Guerra Mundial (1919-1933), mas que, gradualmente, seria modificada nas décadas posteriores.

\section{A ELEVAÇÃO DA FATTISPECIE OU TATBESTAND: CAUSA, ELEMENTO E PRESSUPOSTO DA OBRIGAÇÃO TRIBUTÁRIA?}

Primeiramente, deve-se considerar que o tratamento do pressuposto de fato, após sua inserção no Código Tributário Alemão, passou a configurar elemento central no debate sobre o fundamento ou causa da obrigação tributária.

Contudo, em primeiro momento, a causa no direito tributário apareceria vinculada às razões (éticas, econômicas ou sociais) para haver a tributação, ao passo que, em segundo momento, na verificação da causa "jurídica" do tributo. Para essa corrente o estudo do pressuposto revelaria em si mesmo a verdadeira causa jurídica do tributo (FONROUGE, s/d, p. 87 e ss). Gradativamente, o fundamento legal enquanto "causa" da obrigação tributária passa a ser prevalecente (INGROSSO, 1937, p.98).

Mas a influência econômico-financeira mantinha ainda nesse assunto grande importância. Nesse sentido, forte influência teve a contribuição de Griziotti (1958, p.344 e ss), ao identificar a causa do tributo baseada na capacidade econômica do contribuinte. Outros autores, sem necessariamente contrariar a opinião de Griziotti, a exemplo de Dino Jarach (1993, p.232-252), Berliri (1956, p.116-117), Ezio Vanoni (1952, p.50) e Giorgio Tesoro (1938, p.172) delimitaram a causa variável conforme espécie tributária: no caso dos impostos, seria a capacidade contributiva; no caso das taxas, a contraprestação; no caso das contribuições, o benefício gerado. 
Por outro lado, aos poucos a doutrina anticausal procurou buscar a causa nos elementos incorporados efetivamente na lei tributária e especialmente nos elementos definidos dos pressupostos de fato.

Nesse sentido, entre os anticausalistas, isto é, aqueles autores que reconheciam como causa do tributo a Lei, incluíam-se Giannini (1952, p.133; 1955, p.52-54) e Tesoro (1938, p.74-75), que manifestou importante posição defendendo que a "causa" do direito tributário (da obrigação tributária) repousaria no pressuposto de fato.

Blumenstein (152, p. 01-04), por outro lado, apresentou uma posição intermediária para quem haveria tributos com causa: taxas e contribuições, e os tributos sem causa: impostos.

Em síntese, o estudo da causa ou fundamento do direito tributário registrou três momentos: o primeiro, relacionando a causa do tributo a elementos econômicos, sociais, éticos ou políticos (causalistas); o segundo, relacionando a causa do tributo à lei ou à norma jurídica (anticausalistas); o terceiro, enquanto decorrência expressa do segundo, vinculando à causa do tributo o pressuposto de fato previsto em lei como necessário e suficiente para o surgimento da relação tributária obrigacional.

Naturalmente, a partir do momento em que a doutrina vira-se para o pressuposto de fato enquanto causa ou fundamento legal para a criação da obrigação tributária, a elevação deste conceito legal foi inevitável, e a intensidade de estudos sobre o assunto também. O gradativo reconhecimento do pressuposto de fato abstratamente previsto em lei recebe, no debate causal (e anticausal), forte impulso para a elevação deste tema como central para os estudos de Direito Tributário, incluindo a literatura tributária brasileira, desde seus primeiros passos (SOUSA, 1943, p 15-16).

Assim, quando o pressuposto de fato (previsto em lei) passa a substituir outras causas possíveis (e extrajurídicas) para o surgimento da obrigação tributária, começa efetivamente a e desenvolver a chamada "glorificação do fato gerador" que, de certa forma, daria os primeiros passos para a elevação da atenção à própria estrutura do pressuposto de fato relacionado à obrigação tributária, fundamentado na lei. Assim, a relação tributária torna-se jurídica (obrigacional) de Direito Público, afastando-se de considerações extrajurídicas ou das premissas contidas no Direito Civil. (HENSEL, 1956, p.50; p.71-72), ainda que outras teorias, como a teoria das relações jurídicas concêntricas, de Nawiasky (1982, p. 54), indicassem ausência de hierarquia legal entre contribuinte e fisco (BUJANDA, 1985, p.33), equiparando a relação obrigacional tributária (entre fisco e contribuinte) à relação obrigacional entre dois indivíduos fundamentados no direito privado.

A teoria das relações jurídicas concêntricas encontrou, contudo, severas críticas, sobretudo por considerar a igualdade entre as partes da relação tributária como se estivessem no regime aplicável a uma relação de direito privado. Esta posição, não foi recebida sem críticas como 
ponderam Alcides Jorge Costa (1998, p.21-35) e Ezio Vanoni (1952, p.95-96), não prevalecendo na literatura tributária, que reconheceu as peculiaridades da relação tributária obrigacional, bem como de suas distinções perante a obrigação de direito privado.

$\mathrm{Na}$ sequência, a literatura italiana, apesar de fortemente influenciada pelas lições germânicas, apresentou algumas diferenciações (a exemplo da tradição financista), o que influenciou no estudo da relação jurídica tributária e do pressuposto necessário ao seu surgimento (GRIZIOTI, 1958, p. 50; GIANNINI, 1956, p.11), já que o interesse italiano pelos estudos relativos ao pressuposto de fato relacionava-se diretamente à importância gradualmente relegada pela doutrina italiana à análise da relação jurídica tributária.

Muitos autores italianos debruçaram-se sobre o tema, o que acabava gerando também remissões ao "pressuposto" para que a relação tributária surgisse. As contribuições italianas ao estudo do pressuposto de fato apresentaram fortes semelhanças às contribuições germânicas, caminhando rumo à glorificação da fattispecie enquanto elemento central do direito tributário.

Segundo Berliri (1956, p.233), a obrigação tributária somente pode ser definida com base na consequência derivada da concretização do fato jurídico que, verificado na vida real, dá origem a essa mesma obrigação tributária.

Nesse panorama, Giannini foi o autor italiano que mais influência deteve sobre a construção da concepção da relação jurídico-tributária (GIANNINI, 1955, p.73; GIANNINI, 1952, p.125; GIANNINI, 1937, p. 25-30). Com o aporte de Giannini, entre outros, a doutrina italiana majoritária inclinou-se para conceber a relação tributária como relação jurídica obrigacional, e, naturalmente, a situação prevista em lei como pressuposto para instaurar a relação jurídica tributária obrigacional também foi estudada com semelhante afinco.

$\mathrm{Na}$ interpretação de Giannini, a relação jurídico-tributária é uma relação complexa, em que a obrigação de pagar o tributo, ainda que essencial, ainda que fim último do poder financeiro, apresenta conexão com outros direitos, obrigações e deveres, correlacionados entre os sujeitos da relação jurídico-tributária. Reconheceram, na relação jurídica tributária obrigacional dois polos: o devedor e o credor, repousando sobre o objeto (que pode ser o pagamento do tributo, de penalidade pecuniária ou a prestação positiva ou negativa de alguma conduta no interesse da fiscalização).

Esta posição terá adesão da maioria dos autores italianos, como Puglièse (1939, p.133), Berliri (1957, p.43 e ss), Vanoni (1952, p. 101; 1962, p.10-27;37-56), Jarach (1993, p. 370), além dos latino-americanos Giuliani Fonrouge (1973, p.87), Rafael Bielsa (1953, p.133), Héctor Villegas (1980, p.100-101), entre muitos outros, reconhecendo inclusive a existência da obrigação tributária como componente principal da relação jurídico-tributária, aliada às obrigações, direitos e deveres que conjuntamente formam a relação jurídico-tributária.(BUJANDA, 1985, p. 33) 
Por outro lado, contrária à doutrina da relação jurídica obrigacional, defendida pelos autores italianos supracitados, sedimentou-se paralelamente a concepção denominada "procedimentalista" na Itália, ou, na terminologia adotada por Sainz de Bujanda, "Doutrinas Dinâmicas" ou "Funcionais" (1985, p.33). Essa interpretação da relação tributária, cujos principais representantes italianos foram Gian Antonio Micheli (1975, p. 167) e Mafezzoni (1967, p.61), defendia, segundo Alcides Jorge Costa (1998, p. 21-35), a não existência de uma obrigação tributária, mas um conjunto de atos e procedimentos destinados a harmonizar duas situações jurídicas (em face do poder de império e do dever correlato do contribuinte). Nesse aspecto, há, de certa forma, uma retomada da concepção do poder de imposição em face da relação jurídica obrigacional da doutrina majoritária.

Mas, curiosamente, os elementos de distinção trazidos pela doutrina funcional não alterava a estrutura elementar do pressuposto de fato, reconhecendo neste instituto o pressuposto para autorizar a criação do procedimento tributário respectivo (COSTA, 1998, p.21-35; BUJANDA, 1985, p.33).

De qualquer forma, a grande vinculação do hecho imponible à obrigação tributária não deve surpreender, já que, conforme bem assinala Sainz de Bujanda, “(...) Na realidade, o nascimento da obrigação tributária e a produção do hecho imponible são fenômenos que aparecem indissoluvelmente unidos, no sentido de que se produzem no mesmo instante e de que não podem conceber-se um sem o outro" (BUJANDA, 1966, p. 262-263).

Nesse contexto, inicialmente parcela da doutrina italiana tencionou incluir o pressuposto de fato enquanto elemento fundamental da obrigação tributária. Puglièse, por exemplo, ressaltou a importância dos elementos da obrigação tributária: a lei e "o fato indicado como condição objetiva, necessária e suficiente para que nasça a obrigação" (PUGLIÈSE, 1939, p. 103-135).

Por outro lado, Giorgio Tesoro (1938, p.74-75), não ligando expressamente a delimitação do pressuposto à estrutura da obrigação tributária, vinculou os seguintes elementos: a) sujeito ativo; b) sujeito passivo; c) objeto (constituído por qualquer prestação devida por um sujeito passivo a um sujeito ativo - com o qual se extinga a obrigação tributária); d) causa jurídica (a causa ou fundamento pelo qual o tributo seja estabelecido em favor do Estado para que o sujeito passivo o pague).

Jarach segue assinalando os seguintes elementos da relação jurídico-tributária: a) sujeito ativo, titular da pretensão (do crédito tributário, que seria o credor do tributo); b) o sujeito passivo principal ou devedor principal do tributo (contribuinte e outros sujeitos passivos codevedores ou responsáveis); c) o objeto, ou seja, a prestação pecuniária, que é o tributo; d) o fato jurídicotributário, isto é, “(...) o pressuposto de fato ao qual a lei vincula o nascimento da relação tributária”. (2004, p.92-93) 
Assim, parte da doutrina tributária italiana passou a considerar o pressuposto de fato como elemento da obrigação tributária, ao passo que outros autores o indicaram como pressuposto necessário para o imediato surgimento da obrigação tributária. A consequência teórica da inclusão do pressuposto de fato como elemento da obrigação tributária ironicamente indicaria a priori preferência pela análise da obrigação tributária (e secundariamente) ao pressuposto de fato enquanto objeto da obrigação tributária (BUJANDA, 1966, p. 286-296).

De qualquer forma, ainda que guardando essas peculiaridades, seja "fora" ou "dentro" da relação jurídica obrigacional, o estudo latino-americano do pressuposto de fato que deflagraria essa relação jurídica, dedicando análoga atenção à demonstrada na literatura de língua alemã e italiana, pois para estudar a estrutura da obrigação tributária era necessário também apreender previamente a situação de fato que ensejava o nascimento dessa obrigação fiscal (MICHELI, 1982, p.324-325). Assim, o tratamento da situação de fato que enseja a obrigação tributária recebeu perene atenção dos tributaristas do período em que se consolidou a "glorificação do fato gerador".

Não é por outro motivo que Amílcar de Araújo Falcão, na definição da obrigação tributária principal enquanto obrigação "ex lege" de direito público, compreendeu-a como uma relação jurídica através do qual a prestação de tributos é exigida pelo Estado ou outra pessoa de direito público, atribuindo à lei a fonte da obrigação. Embora considerasse a lei como fonte da obrigação (o que revela sua tendência anticausal), ressaltava que a mesma não seria suficiente para sua instauração (da obrigação), sendo necessário, para o nascimento da obrigação, que “(...) surja concretamente o fato ou pressuposto que o legislador indica como sendo capaz de servir de fundamento à ocorrência da relação jurídica tributária”. (FALCÃO, 1964, p.12-13)

Logo, a doutrina não deixou de reconhecer o fato gerador enquanto pressuposto necessário para a ocorrência da obrigação tributária (ou relação tributária obrigacional), ou mesmo enquanto componente (elemento) da própria relação tributária.

Por isso, ressalte-se, com Jarach, que “(...) todos os elementos subjetivos e objetivos da relação jurídica tributária se resumem a um único conceito de pressuposto de fato definido pela lei”. (JARACH, 1980, p. 137-138).

Naturalmente, tal concepção, ligando o fato gerador à obrigação tributária, necessita da intermediação da lei positivada que preveja abstratamente a descrição desse "fato", para que, a partir da ocorrência de seu correlato fenomênico, autorize juridicamente a criação da obrigação tributária.

\section{A EVOLUÇÃO DA ESTRUTURA JURÍDICA E A GRADUAL DELIMITAÇÃO DOS ELEMENTOS DO PRESSUPOSTO DE FATO: PANORAMA DOUTRINÁRIO NO PERÍODO DA GLORIFICAÇÃO}


A previsão legal da situação de fato que, uma vez ocorrida, tem o condão de autorizar a cobrança do tributo (a partir do nascimento da obrigação tributária e sua verificação por ato administrativo competente), logo gerou a percepção na literatura europeia de que a adequada delimitação de sua estrutura e respectivos elementos era importante indício da relevância do conceito para fins tributários.

Não tardou para a doutrina tributária europeia buscar o delineamento estrutural do suposto de fato e seus elementos componentes. Naturalmente, os elementos da relação tributária obrigacional acabaram imediatamente vinculados ao pressuposto de fato (e incluindo-os enquanto seus elementos), ou, em outros casos, produzindo elementos próprios do pressuposto que não necessariamente se identificariam com essa relação tributária obrigacional (embora mantivessem grande similitude).

Exemplo da dificuldade inicial de delimitação estrutural desses elementos ao pressuposto de fato pode ser identificado na obra de Gustavo Ingrosso, baseado na literatura alemã, para quem os elementos do imposto seriam o sujeito, o objeto e a mensuração. Assim, menciona os sujeitos ativos (Estado que cobra o imposto) e a pessoa que paga (sujeito passivo), que é (enquanto sujeito do imposto) a pessoa juridicamente obrigada a pagá-la (contribuinte). Já o objeto do imposto é a coisa (móvel ou imóvel) ou o direito (mobiliário ou imobiliário) ou complexo de coisas e direitos, o ato jurídico ou fato, que suponha, por si mesmo, indícios relevantes de existência de capacidade contributiva de uma pessoa. O objeto do imposto diferencia-se da fonte do imposto, embora coincidam em alguns momentos. A mensuração do imposto ou medida do imposto é a quantidade de dinheiro que o sujeito deve pagar, geralmente determinada por cálculo aritmético, onde a coisa ou fato que é objeto do imposto tem um valor pecuniário exprimido por uma cifra. Esse valor é a base de cálculo da mensuração do imposto (valore imponibile). Já a quota de cada unidade aplicável à base de cálculo é a taxa ou alíquota do imposto, determinando-se assim o montante do imposto (INGROSSO, 1937, p.17-22).

$\mathrm{Na}$ verdade, a eleição dos componentes do pressuposto de fato sem grandes transtornos apresentava semelhança com os elementos componentes da obrigação tributária. Afinal, para que o fato seja realizado, devem existir sujeitos, assim como a prática de uma conduta prevista (objeto). Tão evidente quanto esses componentes foi a percepção da necessidade de se auferir um valor a ser pago a título de tributo (e representativo do objeto da obrigação tributária). Logo, foi quase natural a identificação de seus componentes com aqueles que firmariam a obrigação tributária, muito embora não fosse incomum eventual dificuldade de distinção dos elementos da obrigação tributária com os elementos do pressuposto de fato, que somente seriam melhores esclarecidas na literatura recente. 
De qualquer forma, vale a pena apresentar rápido panorama sobre as diversas propostas trazidas pela literatura tributária, partindo-se da imprescindível contribuição histórica de Albert Hensel, que delineou os principais elementos do pressuposto de fato do imposto: a) credor do imposto: é o titular da pretensão; b) devedor do imposto: é o obrigado à prestação. Ao estabelecer os primeiros elementos do Tatbestand, elenca valiosas considerações, como a diferenciação entre capacidade jurídica (civil) e tributária, assim como a responsabilidade; c) lado objetivo do pressuposto: para que surja uma relação obrigacional do imposto, deve ocorrer a existência de bens, a conclusão de negócio jurídico ou a verificação de um fato econômico que a lei considere "base de um débito do imposto". A esses elementos, Hensel indicou a denominação lado objetivo do pressuposto (lato oggettivo della fattispecie, na tradução italiana), que, evidentemente, devem ser consagradas pela lei e, portanto, conceitos jurídicos de direito tributário, em nada relacionados aos conceitos econômicos da ciência das finanças (note-se aqui também esforço na diferenciação entre conceitos econômicos e jurídicos); d) base de débito do imposto: a definição do objeto do imposto não basta para a configuração suficientemente jurídica desse elemento do pressuposto, e por isso chama de "medida fiscal" (misura fiscale, na tradução italiana), a ordem de grandeza aplicável ao objeto do qual surge o resultado fiscal. e) Taxa do imposto: a taxa do imposto seria a soma de dinheiro paga por cada unidade do imposto, geralmente podendo ser certa quantidade ou percentual aplicável às unidades fiscais. (HENSEL, 1952, p; 73-78, 79-85,103).

Assim, na medida em que se percebia a importância da correta delimitação do pressuposto, crescia a atenção pela correta determinação de seus componentes. Afinal, quanto melhores delimitados e definidos, maior a segurança e a certeza nas relações tributárias, e assim pensava Vanoni, ao determinar a necessidade de que na fattispecie seja facilmente reconhecível até mesmo o montante do tributo (|1962, p.293-297).

Já na construção de Tesoro (1938, p.144-173), os elementos do pressuposto de fato, seriam dois somente: a) elemento material - que consiste no objeto do tributo em sentido econômicofinanceiro, e por isso a existência de uma renda, ou de um patrimônio, o transferimento de um bem, etc; b) e um elemento pessoal - que consiste em uma certa relação de fato ou jurídica em que deve vincular o sujeito passivo da obrigação tributária com o elemento material.

$\mathrm{Na}$ interpretação de Vanoni, no intuito de determinar com precisão o processo de adequação típica do fato fenomênico ao pressuposto de fato, elencou as seguintes etapas ou momentos: a) a verificação de um fato, que se insere entre a fattispecie tributária e sua qualificação jurídica; b) verificação dos elementos objetivos com que o tributo é mensurado (base imponível - base imponibile); c) mensuração da base imponibile, que passa pelo processo de avaliação em dinheiro; d) cálculo do imposto devido, através da aplicação da "quota d’imposta" (alíquota) no cálculo da base imponível (VANONI, 1962, p. 321-334). 
Note-se que Vanoni entendia que a operação lógica que exalta a verificação da fattispecie tributaria (e, consequentemente, o montante do tributo devido) não implica somente em uma indagação de fato (fenomênico), mas também a redução do fato dentro os limites da regra de direito, e, portanto, um fato jurídico (VANONI, 1962, p. 333-345).

A estrutura do débito do tributo apresentada por Giannini (1936, p. 46-51), por outro lado, enquanto componente da própria obrigação tributária, possui os seguintes elementos constitutivos: a) elemento material: que seria mais propriamente o objeto do tributo, servindo de critério diferenciador entre um imposto e outro: patrimônio; produção de uma renda, etc); b) o segundo elemento (pessoal) do pressuposto consiste nos sujeitos do imposto, por sua vez relacionados ao elemento material.

Embora não diretamente reconhecendo à base "imponibile" e à alíquota (tasso) como formadores de um terceiro elemento, inclui-os como componentes externos dos dois elementos, onde a alíquota se aplicaria à base imponível, ambos estabelecidos por lei ou norma distinta da que fixaria os elementos material e pessoal. Além desses elementos (material, pessoal, base imponível e taxa), Giannini não reconhecia outros elementos juridicamente relevantes para determinação do débito tributário (Istituzioni, p. 97). Note-se, contudo, que até o presente momento o raciocínio de Giannini foca a relação tributária obrigacional, e não diretamente o pressuposto de fato.

$\mathrm{Na}$ sequência, Giannini inclui os elementos do pressuposto (de maneira análoga à construção do débito tributário) na seguinte passagem:

O débito do imposto surge, como sabemos, quando se verifica a situação de fato estabelecida pela lei como pressuposto da imposição. Foi também revelado que a esta situação de fato possui dois elementos: um (material) consistente na condição das coisas ou no acontecimento, objetivamente considerado, a que a lei atribui o imposto; e a outro (pessoal) constituído pela relação em que deve alcançar o sujeito passivo com que primeiro elemento porque nasça a carga do débito do imposto (GIANNINI, 1955, p. 97 e ss).

Na América Latina, Amílcar de Araújo Falcão, a partir de sua própria definição do fato gerador, noutro passo, elencou os seguintes elementos:

a) a previsão em lei; b) a circunstância de constituir o fato gerador, para o direito tributário, um fato jurídico, na verdade um fato econômico de relevância jurídica; c) a circunstância de tratar-se do pressuposto de fato para o surgimento ou a instauração da obrigação ex lege de pagar um tributo determinado (1964, p. 13).

Note-se também que Jarach, diferenciando-se de Giannini, posiciona-se:

$\mathrm{Na}$ análise jurídica da relação obrigacional se adota outro enfoque e outra terminologia. Concebida a relação jurídica tributária como relação pessoal, considera-se que o primeiro elemento da obrigação pessoal consiste nos sujeitos 
ativos e passivos; o segundo elemento é o objeto ou a matéria imponível, identificando neste conceito os fatos objetivos que dão origem à obrigação.

E arremata:

Não compartilho dessa posição doutrinária e, pelo contrário, creio que é fonte de erros e confusões. Os sujeitos da obrigação tributária não são um elemento a priori, nem desvinculado do pressuposto de fato objetivo. Não existe uma relação intersubjetiva com precedência da obrigação tributária concreta que surge da verificação de fatos definidos pela lei (JARACH, 1980, p. 136-137).

Por outro lado, Jarach manteve harmonia no sentido de que “(...) a relação jurídica tributária, enquanto nasce da lei, exige como requisito fundamental para seu nascimento a verificação na realidade fática o fato ou os fatos definidos abstratamente pela lei como supostos da obrigação" (1980, p.136).

Berliri, em outro retrospecto, assevera que o acontecimento em que se concretiza o fato gerador pode ser examinado sobre vários aspectos e, em particular, sob o aspecto temporal (profilo temporale), sob o aspecto espacial (profilo spaziale), sob o aspecto quantitativo (profilo quantitativo), ao passo que para Sainz de Bujanda, os elementos constitutivos do fato imponível são: a) elemento objetivo; aspecto espacial; aspecto temporal; aspecto temporal; aspecto quantitativo (BUJANDA, 1966, 401-418).

Ressalve-se que, em momento posterior, as condições de espaço e de tempo foram gradativamente incluídas, o que, na verdade, não deve causar surpresa, pois a preocupação com essas condições já era latente, especialmente se observadas largas digressões sobre a eficácia da lei tributária no tempo e no espaço, assim como as classificações dos tributos em face do tempo (instantâneas, continuadas, etc.) que sempre eram objeto dos cursos e manuais de direito tributário naquela época.

Assim, a tendência manifestada pela doutrina europeia e latino-americana naquele período tendia para delimitar os seguintes elementos (lados ou aspectos): a) elemento material ou objetivo, consistente na conduta praticada ou no fenômeno objetivamente ocorrido; b) elemento pessoal (consistentes nas pessoas envolvidas pelo tributo, embora em primeiro momento seja possível identificar maior preocupação na delimitação do sujeito passivo da obrigação); c) o cálculo do tributo, geralmente formado pela base de cálculo e a alíquota (taxa).

Naturalmente, com a evolução histórica do instituto outros elementos foram melhores identificados (como o temporal e o espacial, com maior atenção na América Latina), mas, efetivamente a doutrina europeia e latino-americana acabou dedicando-se a desenvolver considerações sobre os diferentes elementos supramencionados. 


\section{OS REFLEXOS ESTRANGEIROS NO ESTUDO DA ESTRUTURA DO FATO GERADOR OU FATO IMPONÍVEL NA LITERATURA TRIBUTÁRIA BRASILEIRA}

A utilização ou a busca pela delimitação dos elementos da norma tributária apresenta três fases no Brasil, refletindo a produção doutrinária estrangeira. Em primeiro lugar, a definição de seus elementos, preocupação acessória à delimitação do pressuposto de fato ou Tatbestand, aparece primeiramente na Ciência das Finanças, para depois desaguar na literatura tributária emergente a partir da década de quarenta do século XX. Mas, entre as décadas de quarenta e sessenta, a delimitação dos elementos não ultrapassou as conquistas oriundas da produção estrangeira, isto é, manteve-se praticamente alinhadas enquanto reflexos do que havia sido produzido na literatura europeia e latino-americana. Apenas a partir da década de sessenta é que a delimitação dos componentes do tributo passam por maior atenção, pelos motivos que serão exposto nas linhas abaixo.

No século XIX, a literatura dedicada aos tributos encontrava respaldo na produção financista estrangeira, reproduzindo as contribuições estrangeiras ao estudo das Finanças Públicas e, por extensão, à tributação. Muitos conceitos ou expressões trabalhadas por financistas acabaram também reproduzidas ou traduzidas para a realidade jurídica nacional. As expressões objeto do imposto, assento do imposto, incidência, taxa (alíquota) e base ou medida do tributo (base de cálculo) eram expressões correntes na literatura financista do século XIX e início do século XX (CASTRO, 1910, p. 95-205; MACHADO, 1974, p. vii e ss).

Dídimo Veiga (1927, p.172), por exemplo, já mostrava conhecimento sobre o objeto do imposto, elevando a importância da identificação precisa dos elementos substanciais do imposto. A identificação desses elementos seria viável a partir da análise prévia da fonte ou finalidade do tributo. Também assumia como necessário a apuração da incidência e do "assento" para verificação de sinais denunciativos de "assignação symbolica da tarifa tributaria". Para Didimo Veiga, também baseado em Nitti (1937, p. 331), dois fenômenos seriam essenciais para a verificação da tributação: 1) incidência ("phenomeno de apprehensão do contribuinte pelo imposto"); 2) assento: é a matéria sobre o qual recahe o imposto (produto ou riqueza tributadas).

Ainda, Dídimo Veiga (1927, p. 172), citando Orlando, elevou três elementos fundamentais para a tributação: a) sujeito do imposto, que é a pessoa a quem suporta a obrigação de realizar a contribuição; b) a fonte, que é o rendimento ou a riqueza disponível; c) o objeto, que é a espécie ou domínio, de indústria, o ato de produção, de consumo e semelhante, “(...) que se prenda à fonte referida" (VEIGA, 1927, p. 178 e ss)

Note-se que tais elementos acabariam influenciando de forma determinante a produção jurídica brasileira a ponto de que determinados temas tradicionalmente objetos de reflexões 
financistas, seja pela legislação, doutrina ou jurisprudência italiana e francesa (MACHADO, 1974, p. vii-viii) acabarem refletidos como temas "tipicamente jurídico-tributários".

No mesmo sentido, essa característica pode ser observada no histórico Relatório do Ministro da Fazenda, de autoria de Rui Barbosa, tratando especialmente do imposto de renda, mas também analisando diversos aspectos dos impostos, com especial atenção ao assento e às taxas de proporção (alíquotas), do cálculo da renda, bem como aos sujeitos do tributo (BARBOSA, 1949, p. 52-54, 67116).

Ademais, Vários outros autores oriundos da Ciência das Finanças ou do Direito Público trataram de repercutir esses ensinamentos, a exemplo de Epitacio Pessoa (1959, p. 150 e ss), ao se referir à base para o cálculo da "taxa".

Assim, a produção inicial na área fiscal (no campo do Direito Tributário) mantinha refletidos os ensinamentos construídos pela Ciência das Finanças estrangeira.

Na década de quarenta, porém, João Martins de Oliveira (1943, p. 14), a propósito do "pressuposto de fato" ou "pressuposto fiscal”, e já refletindo a literatura jurídico-tributária europeia (sobretudo italiana), defendeu que essa situação de fato é constituída por dois elementos: o elemento material (o ato, o fato, a coisa ou a mera qualidade do indivíduo, a exemplo da sucessão, da transferência do imóvel, a renda, etc), e o elemento pessoal (relação jurídica, ou de ato, que liga o sujeito passivo do imposto ao elemento material).

Oliveira, assim, já ligava o pressuposto de fato (e seus elementos) à obrigação tributária (OLIVEIRA, 1943, p.10 e ss; p. 53-54), isto é, sob o ponto de vista jurídico (e não mais financista).

Naturalmente, a influência da literatura de Jarach (1980, p. 136; 2004, p. 92 e ss) foi determinante no período, sobretudo na literatura latino-americana (com a obra "El Hecho Imponible"), especialmente na delimitação do fato imponível (imagem abstrata que se realizada no mundo fático torna-se jurídica) e compreendendo os impostos enquanto obrigações (relações jurídicas pessoais em que uma pessoa é obrigada a pagar o tributo a outra).

Note-se que Jarach, além de mostrar importantes contribuições na delimitação dos contornos estruturais do tributo, foi também foi considerado integrante da Escola da Glorificação do Fato Gerador, já que concedia ao pressuposto de fato (enquanto elemento da obrigação tributária) grande importância, considerando-o o centro do direito tributário substantivo (JARACH, 2004, p. 92 e ss).

Porém, na delimitação da estrutura do fato imponível, Jarach também refletiu a influência italiana e germânica (sobretudo Giannini e Hensel), na estruturação dos seus elementos, mantendo atenção prioritária ao "lado objetivo" e "lado subjetivo" do pressuposto de fato (considerando-o enquanto próprio objeto da relação tributária) (JARACH, 2004, p. 92 e ss). 
$\mathrm{Na}$ tradição brasileira, contudo, a influência francesa, foi determinante na configuração do pressuposto de fato e de seus elementos, especialmente a partir da publicação da tradução dos estudos franceses de Gastón Jèze (1945, p. 50-63; 1946, p.62-63) a propósito do Fato Gerador do Imposto (fâit genératour d'Impôt), ganhando apoio da literatura (e legislação nacional), conforme se observa em Amílcar de Araújo Falcão (1964, p. 13).

Entretanto, o importante trabalho de Jèze ("O Fato Gerador do Imposto"), apresentando influência financista, de curta extensão, preocupa-se mais em delimitar o conceito de "fato gerador" do que precisar seus elementos estruturais. $\mathrm{O}$ fato gerador do imposto seria, para Jèze, “(...) o fato ou o conjunto de fatos que permitem aos agentes do fisco exercerem sua competência legal de criar um crédito de tal importância, a título de tal imposto, contra tal contribuinte"(1945, p. 50 e ss).

Assim, o estudo de Jèze não apresentava como elemento central a identificação dos elementos do pressuposto de fato, mas a sua elevação enquanto pressuposto para o surgimento do tributo. Na literatura francesa, ressalve-se, em face da influência financista, havia também certa preocupação na delimitação do fato gerador em face da base de cálculo (TROTABAS, 1975, p.2021).

Mas Jèze comprova essa preocupação ao definir o fato gerador (1945, p. 50-65): “(...) o fato gerador é a reunião de todas as condições para que um indivíduo seja submetido ao impôsto geral".

Não obstante, a literatura tributária brasileira, nas décadas de quarenta e cinquenta, no Brasil, manteve maior atenção aos estudos de Jèze, que não definiam com clareza os componentes do tributo, ao contrário de Jarach na Argentina e Oliveira (por influência italiana) no Brasil. Como a expressão "fato gerador" foi a prevalecente, foi natural que tal tendência fosse seguida na literatura tributária brasileira, conforme se observa nos primeiros estudos de Rubens Gomes de Sousa (1946; p. 58-63) onde Sousa já identificava o fato gerador enquanto "fato material que demonstra a criação, a posse, ou a transmissão de uma riqueza, e do qual, nesse pressuposto, a lei faz depender a incidência, identificando o fato gerador do imposto como causa próxima da obrigação tributária, ou a "causa próxima que a lei faz derivar a incidência" (SOUSA, 1946, p.58-63). Outros estudos de Sousa também reforçam a importância do termo em sua produção doutrinária (1948, p. 32-59). Para Sousa, já no curso de Introdução ao Direito Tributário ministrado na Escola de Sociologia e Política em 1948, (Introdução ao Direito Tributário - Parte Especial), a teoria da relação jurídica tributária seria elemento central em torno do qual se constrói o sistema do direito tributário, sendo o direito tributário essencialmente obrigacional, ou seja, um direito que disciplina o poder jurídico pelo qual uma das partes (sujeito ativo ou credor) possa exigir da outra parte (sujeito passivo ou devedor, ou contribuinte) o cumprimento de uma prestação pessoal de fazer traduzida pelo pagamento de uma soma em dinheiro. Enquanto objeto da relação tributária, o fato gerador é o fato (único ou conjunto de fatos) "(...) de cuja ocorrência a lei faz depender o direito do Estado ao lançamento do tributo 
em cada caso concreto; o fato gerador, portanto, é, por assim dizer, a mola que põe em movimento todo o sistema", ainda que reconhecesse a validade de críticas adotadas pela literatura à expressão (1950, p. 167 e ss).

A atenção à expressão “fato gerador", graças à Sousa, foi inserida no Anteprojeto de Código Tributário Nacional (artigos 140 e 141, especialmente), e no Projeto de Código Tributário Nacional (artigos 80, 82, 83, 84 e 85), por influência de seu Relatório ao Projeto (1954, p. 192), tendência que manteve em estudos posteriores (SOUSA, 1975, 87-96), assim como em outros autores do período, a exemplo de Carlos da Rocha Guimarães (1953, p.11), Bilac Pinto (1953, p.53-56) e Gilberto Ulhôa Canto (1958, p. 108-112). Esses autores ligavam o fato gerador enquanto elemento (objeto) da obrigação tributária, vislumbrando a necessidade de determinação de seus elementos (com o lançamento) para afigurar possível a tributação. A literatura tributária brasileira, entre as décadas de quarenta e sessenta, manteve preferência pela expressão de Jèze, embora não ignorando a contribuição de Jarach, ligando o fato gerador enquanto pressuposto para surgir a obrigação tributária.

Ainda, influenciado tanto por Jarach como por Jèze, Amílcar de Araújo Falcão reconheceu a necessidade de delimitação prévia conceitual do fato gerador para que o estudioso possa chegar à fixação das seguintes noções:

\begin{abstract}
a) identificação do momento em que nasce a obrigação tributária principal; b) determinação do sujeito passivo principal da obrigação tributária; c) fixação dos conceitos de incidência, não incidência e isenção; d) determinação do regime jurídico da obrigação tributária: alíquota, base de cálculo, isenções, etc; e) distinção dos tributos in genere; f) distinção dos impostos in specie; g) classificação dos impostos em diretos e indiretos; h) eleição do critério para a interpretação da lei tributária; i) determinação dos casos concretos de evasão em sentido estrito (Steuerumgehung); j) estabelecimento dos princípios de atuação da discriminação constitucional de rendas no Brasil: definição da competência impositiva e determinação dos casos de invasão de competência e de bitributação (1997, p. 04-05;22).
\end{abstract}

Falcão, ainda, considerava que o fato gerador seria essencial para a determinação da base de cálculo (FALCÃO, 1964, p.155), de cuja realização dependeria o surgimento do efeito jurídico apropriado (obrigação tributária).

Com a eleição prévia do fato gerador para viabilizar a definição dos elementos acima, elevou-se rapidamente a importância do tema concedida pela literatura tributária brasileira, o que se reforçou com a manutenção da expressão no Brasil, que veio através da consolidação legislativa do Código Tributário Nacional (art.114), conforme pode-se observar em Falcão (1964, p. 13-19) e Ruy Barbosa Nogueira, ainda que este último também utilizasse "pressuposto de fato da incidência" ou "fato imponível” ou "suporte fático" (1964, p. 17-18; 1965, p.92). 
Assim, no período de "glorificação do fato gerador", o pressuposto de fato, considerado enquanto "causa" da obrigação tributária, ou como elemento da obrigação tributária (objeto), passa a receber atenção quanto aos seus elementos ligando-os à própria obrigação tributária (cuja realização do pressuposto legal faz nascer, enquanto efeito jurídico, a obrigação tributária).

Por tais motivos, até aquele momento, desenvolveu-se ambiente propício à maior atenção aos elementos, ou "lados" objetivo e subjetivo no âmbito do pressuposto de fato, pois inerentemente ligados à obrigação tributária, ainda que a publicação de outros estudos, como o de Jarach e Jèze, oferecessem impulso para o aperfeiçoamento posterior da problemática, mesmo que sob premissas absolutamente distintas, conforme será observado no tópico seguinte.

\section{O INÍCIO DO NORMATIVISMO TRIBUTÁRIO NO ESTUDO DO "FATO GERADOR", A CONTRIBUIÇÃO ESTRUTURAL DE ALFREDO AUGUSTO BECKER, GERALDO ATALIBA E RUY BARBOSA NOGUEIRA}

O normativismo dogmático no Brasil tem grande impulso a partir da década de sessenta do século XX, influenciado por determinados fatores refletidos na doutrina da época, como a publicação, em 1960, da tradução portuguesa da obra "Teoria Pura do Direito", de Hans Kelsen. Assim, o acesso mais facilitado à obra gera importantes repercussões na literatura tributária nacional. Da mesma forma, a influência do cientificismo e do positivismo dogmático-formal começam a aparecer na elaboração de estudos da época, geralmente buscando utilizar o positivismo dogmático-formal como forma de resistência ao ambiente de instabilidade política da época (19641985) trazido pelo Golpe Militar e o regime militar que durou aproximadamente 20 anos.

É importante exemplo desse esforço a obra de Geraldo Ataliba "Sistema Constitucional Tributário" publicado na época, com inspiração direta em Hans Kelsen, tencionando desenvolver um sistema constitucional tributário fechado e rigidíssimo, isto é, protegido contra excessivas alterações.

Sob a perspectiva das estruturas do tributo, ou de seus componentes, ligados tradicionalmente ao pressuposto de fato (fato imponível ou fato gerador) cuja ocorrência fática dependeria o surgimento do efeito jurídico apropriado (nascimento da obrigação tributária), o dogmatismo formal começa a analisá-lo sob seu particular ponto de vista, isto é, a partir do normativismo jurídico. E é a partir dessa época que as obras de Kelsen, Norberto Bobbio, Pontes de Miranda, Carlos Cossio, Eduardo Garcia Maynes, Karl Engish, entre muitos outros filósofos do Direito ou estudiosos de Teoria Geral do Direito, começam a ser propagadas em estudos brasileiros no âmbito tributário. 
Contudo, o primeiro passo dado à elevação da Teoria Geral do Direito e do normativismo jurídico aplicado ao estudo do "fato gerador" na área tributária foi dado por Alfredo Augusto Becker, com a "Teoria Geral do Direito Tributário", de 1963, cuja obra tencionava afastar influências econômicas ou extrajurídicas do estudo do Direito Tributário. Adotando com originalidade o normativismo jurídico e particularmente influenciado por Kelsen, Giannini, Pontes de Miranda, entre outros, passou a investigar a problemática do "fato gerador" sob essa particular visão.

Não por outro motivo, preferiu a expressão "hipótese de incidência" a "Fato Gerador", "Suporte Fático", Fattispecie", ou Tatbestand", argumentando que tal conceito não seria especificidade do direito tributário, mas identificável em diversos ramos do direito. Além disso, defendeu:

Escolheu-se a expressão hipótese de incidência para designar o mesmo que outros autores denominam de "(...) suporte fático ou "Tatbestand" ou "Fato Gerador". Esta última expressão é a mais utilizada pela doutrina brasileira do Direito Tributário e, de todas elas, a mais infeliz por que o "fato gerador" não gera coisa alguma além de confusão intelectual. Para que possa existir a relação jurídica tributária é necessário que, antes, tenha ocorrido a incidência da regra jurídica sobre o "fato gerador" e, em consequência, irradiado a relação jurídica tributária.

Note-se que, para Becker,

a fenomenologia do "fato gerador" (hipótese de incidência, suporte fático, etc.,) não é especificidade do Direito Tributário e nem do Direito Penal, pois toda e qualquer regra jurídica (independente de sua natureza tributária, civil, comercial, processual, constitucional, etc.,) tem a mesma estrutura lógica: a hipótese de incidência ("fato gerador", suporte fático, etc.,) e a regra (norma, preceito, regra de conduta) cuja incidência sobre a hipótese de incidência fica condicionada à realização desta hipótese de incidência (BECKER, 1963, p.318-319).

Becker, por outro lado, foi expressamente influenciado por Pontes de Miranda, que reconhecia a importância do momento e do lugar em que se consideraria ocorrido o fato jurídico, além de definir “(...) no suporte fático, o seu núcleo, ou melhor, os elementos que compõe o seu suporte fático" (fatos jurídicos são elementos do suporte fático), sendo que um deles sempre será o cerne, e dele dependerá a data dos direitos, e é sobre ele que se ligará a regra de direito intertemporal (MIRANDA, 2000, p.13 e ss).

Não é coincidência o fato de Becker dedicar atenção expressa à estrutura (ou composição) da hipótese de incidência, mais especificamente em relação ao seu núcleo e demais elementos adjetivos (BECKER, 1963, p. 90 e ss).

Para Becker, na dissecação da hipótese de incidência, seja ela qual for (e por quantos fatos ou atos for formada), verifica-se que essa é composta por um único núcleo e de um ou mais 
elementos adjetivos, somente realizada na época e no espaço previstos na coordenada de tempo e espaço previstas na regra. Basicamente, entende que o núcleo, enquanto elemento mais relevante (pois é este que permitirá distinguir distintas naturezas jurídicas de negócios jurídicos, conferindo o gênero jurídico do tributo), no Direito Tributário, ou seja, na regra jurídica de tributação, o núcleo da hipótese de incidência é a base de cálculo.

Segundo Becker, se por acaso a lei determinar que o mesmo imposto será pago tanto no contrato de compra e venda como na promessa de compra e venda, dessa única lei haverá duas regras jurídicas distintas. Essas duas regras jurídicas terão idêntica regra e distintas hipóteses de incidência, existindo dois gêneros jurídicos de impostos: o imposto de compra e venda, e o imposto de promessa de compra e venda.

No que importa aos elementos adjetivos, Becker salienta que estes, como o próprio nome lhes confere, adjetivam o núcleo, determinando-lhe maior ou menor especificação. Para Becker, o gênero (jurídico) do tributo determina-se pela natureza de sua base de cálculo (núcleo). Contudo, as espécies jurídicas daquele gênero jurídico do tributo podem ser identificadas através de seus elementos adjetivos.

E exemplifica:

Por exemplo, o imposto cuja alíquota é calculada sobre o valor da venda, mas que é cobrado somente quando se trata de venda de bens móveis, tem o gênero jurídico do imposto de venda (núcleo: negócio jurídico da compra e venda) e a espécie jurídica do imposto de venda de bens móveis (elemento adjetivo). Por outro lado se a alíquota daquele imposto for calculada sobre o valor da renda nas vendas de bens móveis, consistirá num outro gênero jurídico de imposto: imposto de renda (núcleo: a renda) e da seguinte espécie jurídica: percebida nas vendas (elemento adjetivo) de bens móveis (elemento adjetivo) (BECKER, 1963, p.331).

Ainda, nessa ampla gama de possíveis elementos adjetivos que poderão servir a especificar o núcleo da hipótese de incidência, existirá sempre um elemento adjetivo que vai estar presente na formação da hipótese de incidência. Este elemento adjetivo é justamente o que liga a hipótese de incidência a uma ou mais pessoas, implícita nos atos, mas expressa em estado de fato.

Os aperfeiçoamentos identificados na construção de Alfredo Augusto Becker, bem como a própria crítica às expressões acima, foram refletidos na literatura nacional, conforme se pode observar em José Souto Maior Borges (1969, p.161-165), que incorporou, na época, a estrutura de Alfredo Augusto Becker, considerando o núcleo e elementos adjetivos na hipótese de incidência, ainda que adotando a expressão "fato gerador". Porém, ainda na década de sessenta, prevaleceu o uso do "fato gerador", embora muitos autores utilizassem tanto "fato gerador" como "hipótese de incidência tributária", enquanto sinônimos.

Por outro lado, não se pode negar que o mérito de Becker no estudo da "hipótese de incidência" foi justamente chamar a atenção para visão distinta daquela tradicionalmente lançada 
ao "fato gerador". Enxergando-a sob a perspectiva normativa (estática e dinâmica, a partir da lógica formal) Becker daria impulso essencial para que o estudo do "fato gerador" passasse a ser realizado sob a perspectiva do normativismo jurídico, pautado na Teoria Geral do Direito e na Lógica Jurídica.

Conceitos classicamente estudados pela literatura anterior, mas sob outros pressupostos, como incidência, isenção, entre outros, passam a ser analisados sob essa perspectiva (estática e dinâmica da regra ou norma jurídica). O tributo passa a ser enxergado como norma (ou regra) jurídica e sua estrutura passa a ser a estrutura da própria regra ou norma. Além disso, ofereceu expressa distinção entre a descrição hipotética do fato (previamente previsto em lei) do fato concretamente realizado, utilizando duas denominações: hipótese de incidência in abstrato; hipótese de incidência in concreto. Tais lições foram refletidas na literatura tributária nacional posterior, ainda que naquele período imediato, prevalecesse a influência do "fato gerador".

Por outro lado, já na década de setenta, a Escola da PUC-SP, liderada por Geraldo Ataliba, começa também a aplicar esses então novos pressupostos ao estudo do Direito Tributário. O positivismo dogmático formal passa a ser a pedra de toque na construção dessa Escola, profundamente influenciada pelo normativismo kelseniano.

Não por acaso, Geraldo Ataliba, respirando esse ambiente, em 1973, publica a "hipótese de incidência tributária", trabalho que avançaria os estudos sobre o "fato gerador", agora analisado sob a perspectiva normativista. E a estrutura do tributo, a partir da subsunção, passa a oferecer visualização diferenciada, agora compreendida enquanto norma jurídica, seja na configuração do fato (aspecto material), em sua conexão com alguém (aspecto pessoal), em sua localização (aspecto espacial) e em sua consumação num momento fático determinado (aspecto temporal). Esses elementos (ou aspectos), quando reunidos unitariamente, determinarão o efeito jurídico desejado pela lei, que será a criação de uma obrigação jurídica concreta, a cargo da pessoa determinada, em momento preciso.

É preciso lembrar que Ataliba, amparado nas lições de Sampaio Dória, Amílcar de Araújo Falcão, e Dino Jarach, reconhece que o fato imponível é um fato jurídico (e não ato jurídico, pois não há interferência da vontade na configuração do fato, que decorre única e exclusivamente da lei).

Ressaltando ainda mais as diferenças entre a hipótese de incidência e o fato imponível, evidencia as peculiaridades atinentes a cada uma delas, quais sejam: a) hipótese de incidência: a.1) descrição genérica e hipotética de um fato; conceito legal (universo de direito); a.2) designação do sujeito ativo; a.3) critério genérico de identificação do sujeito passivo; a.4) critério de fixação do momento de configuração; a.5) eventual previsão genérica de circunstâncias de modo e lugar; a.6) critério genérico de mensuração (base imponível ou base de cálculo). 
Por outro lado, no tocante às peculiaridades do fato imponível, Ataliba identifica as seguintes: a) fato concretamente o ocorrido no mundo fenomênico, empiricamente verificável; b) fato jurígeno (esfera tangível dos fatos); b.1) sujeito ativo já determinado; b.2) sujeito passivo; b.3) ocorrência, dia e hora determinados; b.4) modo determinado e objetivo, local determinado; b.5) medida (dimensão) determinada (base calculada).

Embora assinalando a unidade da hipótese de incidência, ou seja, que esta é indivisível, nem por isso deixou de assinalar os aspectos que a compõem, em partes ou elementos.

$\mathrm{Na}$ verdade, terminologicamente, o autor prefere a expressão "aspectos", em detrimento de outras já mencionadas.

Em síntese, os aspectos essenciais da hipótese de incidência tributária, na leitura de Ataliba, seriam: a) aspecto pessoal; b) aspecto material; c) aspecto temporal e d) aspecto espacial, contribuindo também para a determinação do quantum debeatur a base imponível e a alíquota (ATALIBA, 2006, p.47-106).

As contribuições de Becker e Ataliba refletiram na própria literatura tributária latinoamericana, conforme se pode observar em Dino Jarach que, em estudo posterior, e já refletindo o aperfeiçoamento doutrinário oriundo do dogmatismo normativo (e de Ataliba), passou a defender que o Pressuposto de Fato conteria os seguintes aspectos, que dariam os contornos do Fato Imponível: Aspecto Objetivo - que seria o conjunto de fatos contidos na definição legal do pressuposto; Aspecto Subjetivo - que seria a determinação dos sujeitos obrigados ao pagamento do tributo, bem como o momento da vinculação do pressuposto de fato com o sujeito ativo da obrigação; Base Imponível - que seria a base de medição, traduzida na adoção de parâmetros que serviriam para valorar quantitativamente os fatos cuja verificação origina a obrigação; Aspecto Temporal e Espacial - que seria a determinação no espaço e no tempo desses fatos; Alíquota - que seria a quantidade expressada em uma soma finita ou uma percentagem ou alíquota aplicável à base imponível, que representasse ou produzisse como resultante o quantum devido da obrigação. A alíquota e a base imponível formariam o Aspecto quantitativo. Logo, os elementos do pressuposto vão desencadear os aspectos presentes no Fato Imponível: Aspecto Objetivo, Aspecto Subjetivo, Aspecto Espacial, Aspecto Temporal e Aspecto Quantitativo (JARACH, 1980, p. 136 e ss).

Essa perspectiva é retomada em estudo posterior de relevo, ao elevar o aspecto espacial, temporal a base de medição ou base imponível e o aspecto subjetivo do "fato imponível" (JARACH, 1999, p. 383 e ss).

Seguindo semelhante caminho na América Latina, o uruguaio Ramón Valdés Costa, também apresentou a estrutura do presupuesto de hecho e do hecho generador da seguinte forma: a) aspecto objetivo: que, por sua vez, divide-se em vários subelementos: a.1) descrição do fato gravado ou elemento material; a.2) quantidade da obrigação, por sua vez formado pela base de 
cálculo entre outros elementos unidos ao fato gravado (não menciona expressamente a alíquota); a.3) condições de tempo e lugar. b) aspecto subjetivo: b.1) sujeito ativo (ente central, entes locais descentralizados, pessoas de direito público não estatais); b.2) sujeito passivo: que, por sua vez, divide-se em: contribuintes (pessoas físicas; pessoas jurídicas; entes sem personalidade; entes públicos); responsáveis (representantes; sucessores; agentes de percepção e retenção); substitutos (1993, p. 306).

Reforce-se que nem Jarach nem Valdés Costa aplicaram o normativismo kelseniano na mesma proporção que a literatura brasileira, embora incorporando as valiosas lições trazidas por essa perspectiva de estudo jurídico à estrutura do "hecho imponible", mas refratando outras, a exemplo de Jarach, que preferiu manter-se alinhado ao monismo aplicado ao estudo do pressuposto de fato, mesmo reconhecendo a procedência dos argumentos de Becker e Ataliba (pelo dualismo), isto é, preferiu usar a mesma denominação "hecho imponible" para a situação hipotética abstrata e para o fato jurídico realizado (JARACH, 1980, p. 138-139).

Por outro lado, não obstante a elementar contribuição de Geraldo Ataliba e Alfredo Augusto Becker a partir da década de setenta, a tradição do uso do fato gerador manteve-se firme em estudos do período. Sem ignorar as contribuições de Geraldo Ataliba, Alfredo Augusto Becker e Paulo de Barros Carvalho (adiante apresentadas), pode-se observar maior atenção à influência de Amílcar de Araújo Falcão e Dino Jarach, além da previsão expressa do Código Tributário Nacional (artigo 114), conforme se observa no uso da expressão "fato gerador" em Alcides Jorge Costa (COSTA, 1975, p. 113 e ss), Brandão Machado (1982, p.273-275), Paulo Celso Bergstrom Bonilha (1973, p.310 e ss) e Ruy Barbosa Nogueira, que, adotando o normativismo, mas inspirado em Miguel Reale, e sem refratar os aperfeiçoamentos doutrinários ao tema no período, compreendeu o "fato gerador" a partir da ideia de norma, fato e efeito, estabelecendo que

(...) a disposição da lei tributária é uma descrição hipotética de fatos ou situações que se forem realizados em concreto pelas pessoas, isto é, se as pessoas praticarem os fatos ou situações previamente descritos no quadro da lei, incidirão na tributação. A lei tributária material é uma espécie de fôrma ou matriz. Todos os fatos ou situações descritos pela lei e que daí para diante as pessoas realizarem, preenchendo esse figurino, darão nascimento à obrigação do tributo. É por isso que o Código Tributário Nacional chama essas "fôrmas" de "hipóteses de incidência (art.104,II) (NOGUEIRA, 1975, p.107-108).

Ainda, Nogueira defendeu que, partindo da premissa de Reale, o fato gerador seria composto por três elementos ou aspectos: “(...) a norma ou hipótese de incidência; o fato típico e o efeito jurídico". Assim, para Nogueira, amparado em Erich Danz, defendeu que uma norma hipotética estabelece fatos (elemento de fato) que ao se realizarem produzirão determinado efeito jurídico. Se esses fatos se realizam, produz-se a partir deste momento o efeito jurídico previamente 
previsto em lei. A trilogia "norma-fato-efeito" corresponderia, segundo Nogueira, na teoria tridimensional de Miguel Reale, à “norma-fato-valor” (NOGUEIRA, 1975, p. 110-111).

Considerando ainda os elementos ou aspectos para que a situação se enquadre no modelo da lei para dar nascimento à obrigação tributária, dividiu-os, à semelhança dos doutrinadores já mencionados: $1^{\text {a }}$ ) elemento material ou objetivo: "É a entidade substancial ou núcleo. Em primeiro lugar é necessário que a lei tenha descrito uma situação e que essa mesma situação previamente definida em lei, ocorra em concreto, seja realizada"; $2^{a}$ ) elementos subjetivos: "Não há direitos e obrigações tributárias sem sujeitos". Sujeito ativo é o poder público competente e o sujeito passivo é o contribuinte ou responsável; $3^{\mathrm{a}}$ ) elemento temporal: "é o momento da consumação do fato gerador"; 4a) Elemento espacial - "é o local da ocorrência do fato típico"; $5^{\mathrm{a}}$ ) Elementos quantitativos - "que seriam a dimensão do próprio núcleo" ou elemento material, representando a expressão numérica ou quantitativa do núcleo (base de cálculo e alíquota).

É interessante notar que Nogueira não ignorava a construção dos conceitos elementares (e mesmo terminológicos) desenvolvidos até a publicação de sua obra, preferindo, no entanto, caminhar pela teoria tridimensional de Reale ao invés de adotar a premissa normativa kelseniana, como ocorreu nos estudos sobre a norma tributária desenvolvidos no âmbito da Faculdade de Direito da PUC-SP.

Ademais, a estrutura desenvolvida por Ataliba também seria adotada por outros autores, a exemplo de Roque Antonio Carrazza, que, contudo, não ignorou o uso da expressão fato gerador, com ponderações dualistas:

Não desdenhamos, porém, a expressão fato gerador desde que acompanhada das qualificações abstrato ou concreto; assim: fato gerado abstrato (ou in abstracto), no sentido de descrição hipotética do fato que, acontecido, fará nascer a relação jurídico-tributária, que tem por objeto a dívida tributária, e fato gerador concreto (ou in concreto), na acepção de fato jurídico que, ocorrido no tempo e no espaço, se subsumiu à hipótese de incidência (tipo tributário) (CARRAZZA, 2011,p.119; CARRAZZA, 2006, p. 30-32),

embora o autor prefira utilizar a terminologia: "hipótese de incidência, para designar a descrição do fato que, quando ocorrer, determinará o nascimento da obrigação tributária, e fato imponível, para nominar o evento que realizou, no mundo real, o tipo tributário"(CARRAZZA, 2011,p.119; CARRAZZA, 2006, p. 30-32).

De qualquer forma, na literatura tributária brasileira, o estudo do pressuposto de fato a partir do normativismo jurídico (como visto em Becker e Ataliba) ofereceu diferenciada visão frente ao tradicional enfrentamento do tema.

Ainda, outra obra fundamental para o aperfeiçoamento dos estudos normativistas aplicados ao "pressuposto de fato" foi na mesma época publicada. Em 1974, Paulo de Barros Carvalho 
publicou a "Teoria da Norma Tributária”, cujas peculiaridades teóricas e os respectivos reflexos na doutrina nacional serão analisados no tópico seguinte.

\section{O NORMATIVISMO TRIBUTÁRIO, A REGRA-MATRIZ DE INCIDÊNCIA (E SEUS CRITÉRIOS) E SEUS REFLEXOS NA DOUTRINA NACIONAL CONTEMPORÂNEA}

O normativismo jurídico concebeu a norma jurídica como elemento nuclear do direito (ou ordenamento jurídico coativo, na visão de Kelsen), este concebido enquanto sistema normativo.

A teoria geral do direito e a lógica jurídica trouxeram os fundamentos estruturais para a concepção da norma jurídica como elemento basilar de toda construção teórico-jurídica.

Consequentemente, se a literatura tributária absorveu o normativismo kelseniano, realçando a importância da norma jurídica tributária, é evidente que o fato gerador (abstrato) também passa a sofrer reformulações estruturais, pois o fato gerador (concepção originariamente monista, isto é, usada para descrever tanto o fato concretamente realizado com o suposto normativo) passa a integrar a hipótese ou suposto na estrutura da hipótese de incidência. Em Alfredo Augusto Becker, Souto Maior Borges, e Geraldo Ataliba, nos anos sessenta e setenta já era possível visualizar essa preocupação com facilidade, seja na vinculação da hipótese de incidência e sua dissociação com o fato imponível ou hipótese in concreto.

Porém, também como resultado de esforços doutrinários antecedentes, coube a Paulo de Barros Carvalho aperfeiçoar os pressupostos jurídicos trazidos por Kelsen, Norberto Bobbio, Carlos Cossio, Eduardo Garcia Maynez, Pontes de Miranda, Geraldo Ataliba, Alfredo Augusto Becker, entre outros.

Para Paulo de Barros, o fato gerador (abstrato) é absorvido à noção de norma jurídica tributária em sentido estrito, organizando os componentes (elementos, aspectos ou critérios) a partir da estrutura bimembre da norma jurídica (hipótese e consequência), e vinculando, à luz dos ensinamentos supramencionados, a relação jurídica tributária à realização da consequência jurídica, que, por sua vez, efetivar-se-ia a partir do preenchimento dos requisitos previstos no suposto normativo (hipótese).

Paulo de Barros Carvalho segue aprofundando o esqueleto estrutural da norma jurídica tributária em sentido estrito, estruturando um modelo normativo para cada tributo existente, ou seja, uma "Norma-Modelo", extraída das proposições prescritivas contidas na lei, e que revela todos os critérios existentes para configurar a incidência de determinado tributo. Esse modelo foi também denominado por "Regra-Matriz de Incidência Tributária", expressão largamente adotada pelos estudiosos que aceitaram a estrutura normativa do fato gerador. 
Esse exemplo pode ser demonstrado por José Roberto Vieira, que, relatando o testemunho da literatura posterior, reconhece em Paulo de Barros Carvalho o melhor cultor da Norma Jurídica Tributária (VIEIRA, 1993, p. 55). Na organização estrutural da Norma Jurídica Tributária, deparando-se com diversas classificações quanto à estrutura das Normas Jurídicas Tributárias, fruto do intuito de, como salienta José Roberto Vieira, “(...) arrumar o Direito Posto” (1993, p. 59), Paulo de Barros estabelece a seguinte classificação de normas tributárias: normas que definem princípios; normas que delimitam a incidência tributária; e as normas que preveem providências administrativas (CARVALHO, 2011, p.240-242;296-297; CARVALHO, 2012, p.39 e ss). As que delimitam a incidência tributária, Paulo de Barros denominou-as como normas tributárias em sentido estrito, ou seja aquela que “(...) marca o núcleo do tributo, isto é, a regra-matriz de incidência fiscal". Já as demais normas tributárias foram classificadas como normas tributárias em sentido amplo (CARVALHO, 2011, p. 296-297). Interessa, evidentemente, neste estudo, tão somente a norma tributária em sentido estrito (CARVALHO, 2012, p.59-60), pois ligada à estrutura da regramatriz de incidência.

Assim, tomando como pressuposto a composição estrutural complexa da norma jurídica (hipótese e consequência, ligada pelo dever-ser ou modal deôntico) (CARVALHO, 2012, p. 60), a literatura que acompanha Paulo de Barros reconhece que a regra-matriz de incidência apresenta, como todas as normas jurídicas, a mesma estrutura hipotética-condicional, pois como bem asseverou Paulo de Barros, a regra-matriz de incidência tributária nada mais é do que "(...) uma norma geral e abstrata que atinge as condutas intersubjetivas por intermédio do ato jurídico administrativo de lançamento ou de ato do particular, veículos que introduzem no sistema norma individual e concreta" (CARVALHO, 2012, p. 60).

Nesse aspecto, segundo Paulo de Barros, reforçando a ideia de que normas jurídicas nada mais são do que significações que a leitura do texto desperta no espírito, e, evidentemente, nem sempre coincidindo com os dispositivos através dos quais o legislador distribui a matéria do corpo de linguagem do direito positivo, pode-se dizer, segundo Paulo de Barros, que a proposição que dá forma à regra do direito é uma proposição normativa.

De fato, em Paulo de Barros Carvalho, a estrutura da norma jurídica em sentido estrito, agora cunhada sob a denominação "regra-matriz de incidência tributária", apresentou vantagens metodológicas, pois solidamente embasada nas conquistas normativas da teoria geral do direito, da lógica jurídica e da filosofia da linguagem, por um lado, e, por outro, formulada sob modelo didático que facilitava a compreensão e a identificação dos caracteres elementares do tributo e da respectiva relação tributária.

Aliás, a didática trazida pela adoção da "regra-modelo" é um dos grandes trunfos visualizados em Paulo de Barros, já que mesmo funções consideradas complexas em construções 
teóricas anteriores (como a função do fato gerador de distinguir as espécies tributárias) passavam a depender do correto preenchimento dos critérios previstos na regra-matriz de incidência tributária.

Não que seja possível dividir uma Norma em critérios ou elementos constitutivos. Não é isso. Segundo a literatura que passou a analisar detidamente os componentes estruturais da regramatriz de incidência, a distinção entre critérios ou elementos tem caráter meramente didático, como bem apontou José Roberto Vieira (1993, p.60).

Isso porque, desde sua obra inaugural, no ano de 1974, Paulo de Barros Carvalho, e apoiado fortemente nas lições de teóricos do direito supramencionados (VILANOVA, 1976, p. 17; VILANOVA, p. 37), enquanto adepto do dualismo do fato gerador (separando a hipótese de incidência tributária- este composto pela hipótese e consequente) do fato jurídico tributário (fato jurídico-tributário realizado no mundo concreto) (CARVALHO, 1981, p. 66-67), Paulo de Barros concebeu a "Regra-Matriz de Incidência Tributária", enquanto norma-modelo detentora de dois componentes (1981, p.45-47): a) Hipótese; b) Consequência (1981, p. 113 e ss).

Nesse contexto, emerge a missão do cientista do direito tributário, conceituando a regramatriz de incidência tributária como

(...) esquema lógico que revela a presença de um juízo condicional, em que se conjuga uma hipótese, suposto ou antecedente e um mandamento (um conseqüente ou uma estatuição). A Hipótese (descritor) possui a previsão de um fato hipotético ao passo que a consequência prescreverá a relação jurídica que vai se instaurar, onde e quando vai acontecer (prescritor). $\mathrm{O}$ descritor possui os seguintes critérios (critério material, espacial e temporal). O prescritor possui os seguintes critérios (quantitativo - base de cálculo e alíquota), constituindo o núcleo lógico-estrutural da proposição normativa, chegando-se à regra-matriz de incidência" (CARVALHO, 1996, p. 42-60).

Paulo de Barros, por sua vez, esclarece, quanto aos critérios previstos na hipótese de incidência:

(...) Quais os critérios que poderão servir para identificar um fato lícito, que não acordo de vontades, considerado em si mesmo? O critério material - descrição objetiva do fato - que é o próprio núcleo da hipótese; o critério espacial condições de lugar onde poderá acontecer o evento; e o critério temporal circunstâncias de tempo que nos permitirão saber em que momento se considera ocorrido o fato. Esses são os dados que a análise dos supostos endonormativos possibilitará extrair. Não havendo mais que a descrição hipotética de um fato, tais critérios prestar-se-ão para identificá-lo, perfeitamente (CARVALHO, 1974, p.113; CARVALHO, 2012, p. 335-336).

À realização da Hipótese, enlaça-se uma consequência, que nada mais é do que a Relação Jurídica que envolve o sujeito ativo, o sujeito passivo, e o seu objeto. Nesse sentido: 
Todavia, se os critérios que logramos encontrar nas hipóteses endonormativas tributárias são aqueles que nos dão elementos para reconhecer um fato que poderá acontecer no plano concreto da realidade, os critérios que encontraremos na conseqüência serão atinentes, única e exclusivamente, com a relação jurídica que haverá de inaugurar-se com a ocorrência daquele fato, tudo por força da imputação normativa. E de que maneira nos será possível identificar essa relação jurídica? Sabendo qual o critério para a determinação dos sujeitos - ativo e passivo (critério pessoal) e de que modo será estabelecido o conteúdo do dever jurídico, a cargo do sujeito passivo, portanto o critério quantitativo. Em resumo, na conseqüência das endonormas tributárias teremos dois critérios: a) critério pessoal; e b) critério quantitativo (CARVALHO, 1974, p. 113; CARVALHO, 2011, p.352-414).

Note-se que Paulo de Barros Carvalho insere nesses componentes normativos os critérios (aspectos ou elementos) reconhecidos pela doutrina tributária estrangeira e nacional - do fato gerador. Todos os elementos esboçados pela literatura anterior são adotados por Paulo de Barros, mas o grande diferencial é a disposição desses critérios a partir da visão lógico-linguística da norma jurídica, esforço que não se encontrou com a mesma eficiência em Becker ou mesmo em Ataliba.

Em síntese, a contribuição de Paulo de Barros Carvalho segue a seguinte estrutura: A) a hipótese da endonorma tributária possui os seguintes critérios: a) critério material - formada por um verbo e seu complemento; b) critério temporal - as coordenadas de tempo que permitem verificar as circunstâncias temporais relacionadas ao fato jurídico tributário; c) critério espacial coordenadas que permitem a identificação do local de ocorrência do fato jurídico tributário; B) Já os critérios da conseqüência da endonorma tributária são: a) critério pessoal - que determina os sujeitos da relação jurídico-tributária, e formado pelo sujeito ativo e pelo sujeito passivo; b) critério quantitativo - que estabelece o quantum debeatur - formado pela base de cálculo e alíquota, possibilitando a identificação do valor devido pelo tributo.

Os citados critérios reunidos permitem a visualização da norma-modelo que estrutura cada tributo, segundo a lição de Paulo de Barros Carvalho. Diferenciando-se da Escola de Glorificação do Fato Gerador, Paulo de Barros Carvalho eleva a importância da consequência tributária, motivo pelo qual a contribuição do autor impulsionou análises mais cuidadosas quanto à verificação dos seus componentes normativos.

Por outro lado, na elaboração e identificação dos critérios, aspectos ou elementos da regramatriz de incidência, e sua distribuição entre a hipótese e o consequente, há doutrina que apresenta posições distintas à de Paulo de Barros Carvalho.

Exemplificativamente, Marçal Justen Filho (1985, p.43-46), também apoiando a distinção entre a previsão abstrata e o fato concretamente realizado, concedendo importância à hipótese e ao consequente da norma tributária, prefere utilizar denominação distinta, isto é, chamou de critérios aqueles previstos na hipótese e de determinações os previstos no consequente normativo. Da mesma forma, o autor, assim como Sacha Navarro Coelho (1991, p. 18 e ss), entende que existiria também 
o aspecto subjetivo (ou critério subjetivo) na hipótese, e não apenas no consequente da norma tributária (regra-matriz) (2011, p.604 e ss). Assim, Sacha Navarro Coelho considera a existência de aspectos material, espacial, temporal e pessoal na hipótese, ao passo que inclui os aspectos subjetivo e quantitativo no consequente, assim como Paulo de Barros Carvalho, que inclui os critérios pessoal e quantitativo no consequente normativo.

Por outro lado, no consequente, Marçal Justen Filho prefere falar em determinações subjetivas (que corresponderia ao critério pessoal, segundo a terminologia de Paulo de Barros Carvalho, compondo o sujeito passivo e o ativo) e determinação objetiva, onde estaria a imposição de uma "determinada conduta, devida pelo sujeito passivo em benefício do sujeito ativo (...)". Recorde-se que, para Marçal, por outro lado, embora reconhecendo a existência de critérios de identificação do fato jurídico na hipótese (já que ela as descreve), não a reconhece no consequente, já que esse não descreve, mas constitui determinações ou imposições.

$\mathrm{O}$ consequente determina, assim, o objeto da relação jurídica, e não somente uma quantia em dinheiro. Difere assim, de Paulo de Barros Carvalho, que identifica no consequente o critério quantitativo, de forma mais restrita que Marçal Justen Filho. Segundo o autor, na determinação objetiva, seria possível a identificação das determinações quantitativa, temporal e espacial (FILHO, 1985, p.52-54). Assim, para Marçal, tudo que seja condição de incidência deve ser incluído na hipótese, e na consequência deve ser incluído tudo o que determine a natureza ou extensão da hipótese. Ainda, na lição do mesmo autor, a consequência possui a “(...) determinação teórica da conduta devida, fornecendo os detalhes para a fixação da natureza e da extensão dessa conduta (...)". Por esse motivo, inclui no consequente critério (ou determinação) pessoal, material, espacial e temporal.

Já Sacha Calmon Navarro Coelho entende que no critério quantitativo também se incluiriam adições e subtrações, relativas à maneira, ao lugar e ao momento de realizar o pagamento do tributo (1991, p. 18 e ss).

Em outro retrospecto, no âmbito da estrutura da norma tributária, também merece lembrança a contribuição de Aires Fernandino Barreto sobre a base de cálculo.

Adotando como premissa a estrutura normativa tributária estabelecida por Geraldo Ataliba (para quem os aspectos da hipótese de incidência tributária conteriam o aspecto material, pessoal, temporal, espacial, a base de cálculo e a alíquota), distinguiu expressamente a base de cálculo "in abstrato" (base de cálculo, pura e simples), contida no plano normativo, da base de cálculo "in concreto" (base calculada) (BARRETO, 1986, p.31 e ss; 88 e ss), por sua vez contida no plano de aplicação da lei.

Assim, ainda que com temperamentos, o aperfeiçoamento dos estudos sobre a norma tributária em sentido estrito a partir das premissas do dogmatismo normativo kelseniano acabou 
recebendo maior adesão da literatura tributária pátria, especialmente divulgada e defendida, com maior ou menor adesão, no âmbito da Escola da PUC-SP, reflete-se (ainda que com temperamentos ou peculiaridades) para a literatura tributária em geral, conforme se observa em Celso Ribeiro Bastos (2011, p.187), Roque Antonio Carrazza (2011, p. 117 e ss), Souto Maior Borges (1999, p.55, 81), Humberto Ávila (2012, p.242), Luís Eduardo Schoueri (2011, p. 434 e ss) e Ricardo Lobo Torres (2013, p.243 e ss).

\section{CONSIDERAÇÕES FINAIS}

A leitura histórico-doutrinária acima apresentada demonstra que, na evolução do tratamento da estrutura da norma tributária (e de seus elementos), houve gradual atenção ao pressuposto de fato (Tatbstand), passando pela influência inaugural da Ciência das Finanças, depois transpostas ao Direito Público (Administrativo e Financeiro), para daí, por influência do Código Tributário Alemão, alcançar a literatura tributária europeia. Essa, irradiando diferentes propostas terminológicas, ligam o pressuposto de fato à obrigação tributária (seja enquanto causa, elemento ou pressuposto da obrigação, já que não seriam necessariamente interpretações excludentes), o que acaba refletindo na identificação dos elementos, lados ou aspectos do pressuposto de fato. Na maior parte da literatura os elementos ou lados identificáveis ao pressuposto de fato foram remetidos ao lado ou aspecto objetivo, conectado à conduta objetiva praticada e subjetivo, por sua vez remetidas às pessoas ligadas à obrigação. A medida ou cálculo do tributo, pela base de cálculo e alíquota, seriam componentes do pressuposto de fato e, para diferentes autores, comporiam o próprio objeto da obrigação tributária.

Gradualmente, com a evolução do normativismo jurídico aplicado aos tributos, outros elementos forma melhor visualizados e a própria estrutura normativa fornecida pela Teoria Geral apoiada na Lógica Jurídica, ofereceu caminho para o aperfeiçoamento da problemática. Nesse aspecto, prevalece gradativamente o dualismo terminológico, e a elevação da hipótese ou antecedente normativo, indicando os aspectos objetivo ou material, subjetivo, espacial e temporal, além dos critérios de determinação do quantum debeatur (base de cálculo e alíquota). Porém, com a construção da regra-matriz de incidência, esses aspectos (já posteriormente denominados critérios) passam a ser melhores divididos entre a hipótese e o consequente normativo (pois o tributo passa a ser considerado norma jurídica em sentido estrito).

Naturalmente, a proposição da regra-matriz de incidência desencadeia propostas substitutivas ou de aperfeiçoamento dessa estrutura original, favorecendo olhares gradualmente atentos tanto ao antecedente quanto ao consequente normativo da regra-matriz, o que leva à melhor identificação dos critérios (e determinações) nessa estrutura normativa. 
Portanto, a evolução da identificação dos lados, elementos, aspectos ou critérios (ou determinações) da norma tributária é produto direto de evolução doutrinária ligada à secular preocupação sobre a melhor identificação dos elementos do pressuposto de fato (Tatbestand), pois problemática inerentemente conectada à necessidade de gradativa proteção do contribuinte (ligada à melhor determinação dos requisitos necessários à tributação) perante o exercício do Poder Tributário, já que a tributação se desencadearia mediante a verificação da realização (fenomênica) do fato jurídico tributário (previamente previsto em lei) cuja ocorrência autorizaria a incidência (por lei), isto é, o surgimento da obrigação tributária entre sujeito ativo, o objeto e o sujeito passivo. E, assim, a prévia determinação desses elementos componentes do "Tatbestand" consolida histórico papel na convalidação da relação jurídica obrigacional tributária, pois reflexo da produção literária estrangeira, mas que encontra essencial contribuição e aprimoramento latino-americanos (e brasileiros).

\title{
SOME APPOINTMENTS RELATED TO THE EVOLUTION OF STRUCTURAL ELEMENTS OF THE FACT ASSUMPTION (TAXABLE EVENT OR HYPOTHESIS OF THE TAX INCIDENCE) ON BRAZILIAN TAX LAW.
}

\begin{abstract}
The present study seeks to perform a panoramic analysis of the doctrinal evolution concerning the gradual recognition of the structure of the tax norm, focusing its components (elements, aspects or criteria) through a historical-evolutionary methodological strategy, starting from the first theoretical compositions related to the Tatbestand (pressupposto di fatto or fattispecie). Thus, the present investigation begins with analysis of the theoretical background, especially in the field of Public Economy (Public Finances), Criminal Law and Administrative Law. Then, the controversy of the identification of the criteria is crossed through the notion of cause, element or presupposition of the tax obligation, a recurring theme in the first decades of the 20th century in European literature. In addition, it seeks to understand, from a legal perspective, the different doctrinal positions (European and Latin American, especially) on the structure (and its components) in the period of "glorification of the tax event". After observing the previous doctrinal and legislative experience, it is sought to investigate the Brazilian doctrinal and legislative evolution on the problematic, which was gradually strengthened from the 1940s onwards, but which still remains constant today.
\end{abstract}

KEYWORDS: Taxable Event. Hypothesis of the tax incidence. Incidence Matrix Rule. Tax Legal Norm. Legal Requirements.

\section{REFERÊNCIAS BIBLIOGRÁFICAS}


ALLORIO, Enrico. Diritto Processuale Tributário. Quarta Edizione. Unione Tipográfico Editrice Torinese, 1963.

ATALIBA, Geraldo. Sobre Dino Jarach. In: JARACH, Dino. O Fato Imponível. 2 edição. Tradução de Dejalma Campos. São Paulo: LTr, 2004.

ATALIBA, Geraldo. Hipótese de Incidência Tributária. $6^{\circ}$ Edição. São Paulo: Malheiros Editores, 2006.

ÁVILA, Humberto Bérgmann. Sistema Constitucional Tributário. São Paulo: Saraiva, 2012.

BALEEIRO, Aliomar. Limitações Constitucionais ao Poder de Tributar. Rio de Janeiro: Forense, s/d.

BARBOSA, Rui. Relatório do Ministro da Fazenda. In: Obras Completas de Rui Barbosa. Vol. XVIII 1891. Tomo III. Ministério da Educação e Saúde. Rio de Janeiro: Imprensa Nacional, 1949.

BARRETO, Aires. Base de cálculo, Alíquota e Princípios Constitucionais. São Paulo: Rt, 1986.

BASTOS, Celso Ribeiro. Arts. 113 a 118. In: Comentários ao Código Tributário Nacional. 6 Ed. Volume 2. Arts. 96 a 218. Coord: MARTINS, Ives Gandra da Silva. São Paulo: Saraiva, 2011.

BECKER, Alfredo Augusto. Teoria Geral do Direito Tributário. São Paulo: Saraiva, 1963.

BECKER, Enno; RIEWALD, Alfred; KOCH, Carl. Reichsabgabenordnung. Kommentar. Band I. Köln - Berlin - Bonn - München: Carl Heymanns Verlag K.G., 1963.

BERLIRI, Antonio. Principi di Diritto Tributario. Volume 1. Milano: Dott. A.Giuffrè - Editore, 1952.

BIELSA, Rafael. Estudios de Derecho Público. II. Derecho Fiscal. Buenos Aires: Depalma, 1951.

BONILHA, Paulo Celso Bergstrom. Alguns aspectos do imposto de circulação de mercadorias. In: Direito Tributário. Direção e colaboração do Prof. Ruy Barbosa Nogueira. 1ª Coletânea. São Paulo: José Bushatsky, p. 1973.

BORGES, José Souto Maior. Isenções Tributárias. São Paulo: Sugestões Literárias, 1969.

BORGES, José Souto Maior. Lançamento Tributário. 2a Ed. São Paulo: Malheiros, 1999.

BRANDÃO MACHADO. Apresentação. In: MORAES, OSWALDO de. Curso de Legislação Tributária. São Paulo: Saraiva, 1974.

BUJANDA, Fernando Sainz de. Analisis jurídico del Hecho Imponible. In: Hacienda y Derecho. Vol.IV. Madrid: Instituto de Estudios Fiscales, 1966.

BLUMENSTEIN, Ernst. Sistema di Diritto delle Imposte. Traduzione: FORTE, Francesco. Milano: Dott A. Giuffrè, 1954. 
CANTO, Gilberto Ulhôa. Conferencia da Série. $1^{\text {a }}$ Conferencia do Prof. Gilberto de Ulhôa Canto, realizada no dia 22 de maio de 1956, às 18:00, sobre o tema "Obrigação Tributária, seus pressupostos e elementos". In: Instituto Brasileiro de Direito Financeiro (Filiado à I.F.A.). Publicação n.6. Curso de Direito Financeiro. 1958. Rio de Janeiro - 1958.

CARRAZZA, Roque Antonio. O Fato Gerador da Obrigação Tributária. In: Tratado de Direito Tributário. 2. Coord: Ives Gandra Martins, Carlos Valder do Nascimento e Rogério Gandra da Silva Martins. São Paulo: Saraiva, 2011.

CARRAZZA, Roque Antonio. Curso de Direito Constitucional Tributário. 25 Ed. São Paulo: Malheiros, 2009.

CARVALHO, Paulo de Barros. Direito Tributário: Fundamentos Jurídicos da Incidência. $9^{\circ}$ Edição. São Paulo: Saraiva, 2012.

CARVALHO, Paulo de Barros. Direito Tributário. Linguagem e Método. $4^{\mathrm{a}}$ Edição. São Paulo: Noeses, 2011.

CARVALHO, Paulo de Barros. Teoria da Norma Tributária. $2^{\circ}$ Edição. São Paulo: Editora Rt, 1981.

CARVALHO, Paulo de Barros. Teoria da Norma Tributária. São Paulo: Max Limonad, 1998.

CARVALHO, Paulo de Barros. Curso de Direito Tributário. $17^{\circ}$ Edição. São Paulo: Saraiva, 2006.

CARVALHO, Paulo de Barros. Curso de Direito Tributário. $23^{\circ}$ Edição. São Paulo: Saraiva, 2011.

CARVALHO, Paulo de Barros. Teoria da Norma Tributária. $1^{a}$ Ed. São Paulo: Lael, 1974.

CARVALHO, Paulo de Barros. "Isenções tributárias do IPI em face do princípio da nãocumulatividade.” In: Revista Dialética de Direito Tributário. São Paulo: Dialética, 1998.

CASTRO, Augusto Olympio Viveiros de. Tratado dos Impostos (Estudo Theorico e Pratico). Segunda Edição. Rio de Janeiro: Industria Nacional, 1910.

Código Tributário Alemão. In: Códigos Tributários. Alemão. Mexicano. Brasileiro. $1^{\mathrm{o}}$ edição. Tradução de Souza Diniz. São Paulo: Edições Financeiras S.A., 1965.

COELHO, Sacha Calmon Navarro. Comentários à Constituição de 1988 - sistema tributário. 3. ed., Forense, 1991.

COELHO, Sacha Calmon Navarro. Curso de Direito Tributário Brasileiro. $11^{\text {a }}$ Ed. Rio de Janeiro: Forense, 2011.

COSTA, Alcides Jorge. Da Teoria do Fato Gerador. In: Curso de Teoria Geral do Direito Tributário. São Paulo: Secretaria da Fazenda do Estado de São Paulo. Coordenação da Administração Tributária, 1975.

DERZI, Misabel. Direito Tributário, Direito Penal e Tipo. São Paulo: Rt, 1988. 
FALCÃO, Amílcar de Araújo. O Fato Gerador da Obrigação Tributária. $3^{\circ}$ edição. Rio de Janeiro: Forense, 1997.

FALCÃO, Amílcar de Araújo. O Fato Gerador da Obrigação Tributária. São Paulo: Edições Financeiras, 1964.

FANUCCHI, Fabio. Curso de Direito Tributário. Curso de Direito Tributário Brasileiro. Volume I. $4^{a}$ Edição. São Paulo: Co-edição - IBET - Instituto Brasileiro de Estudos Tributários Editora Resenha Tributária, 1976.

FLEINER, Fritz. Les Principes Généraux Du Droit Administratif Allemand. Traduction de Ch. Eisemann. Paris: Libraire Delagrave, 1933.

FONROUGE, Giuliani. Conceitos de Direito Tributário. São Paulo: Lael.

HENSEL, Albert. Diritto Tributario. Traduzione di DINO JARACH. Milano: Dott. A. Giufrrè Editore, 1956.

GIANNINI, Achile Donato. Istituzioni di Diritto Tributário. Torino: Unione Tipografico Editrice Torinese, 1952.

GIANNINI, Achille Donato. Il Rapporto Giuridico D'Imposta. Milano: Giuffrè Edittore, 1937.

GIANNINI, A.D. I Concetti Fondamentali di Diritto Tributario. Unione Tipográfico Editrice Torinese, 1952.

GRIZIOTTI, Benvenuto. Princípios de Política, Derecho y Ciência de la Hacienda. Trad: Enrique R. Mata. Segunda Edición. Madrid: Instituto Editorial Réus, 1958.

GUIMARÃES, Carlos da Rocha. Introdução ao Direito Fiscal. In: Elementos de Direito Tributário. Curso proferido em 1953 na Fundação Getúlio Vargas. Rio de Janeiro: Edições Financeiras S.A., s/d.

JARACH, Dino. Curso de Derecho Tributario. Tercera Edición. Buenos Aires: Cima, 1980.

JARACH, Dino. O Fato Imponível. Teoria Geral do Direito Substantivo. Traduzido por Dejalma Campos. $2^{\circ}$ edição, 2004.

JÈZE, Gastòn. O Fato Gerador do Imposto (Contribuição à Teoria do Crédito do Imposto). Trad. Paulo da Mata Machado. Revista de Direito Administrativo. Vol. II - Fase I. Julho -1945.

JÈZE, Gastón. Natureza e Regime Jurídico do Crédito Fiscal. In: Revista de Direito Administrativo. Volume III. Janeiro - 1946, Rio de Janeiro - Brasil.

JUSTEN FILHO, Marçal. O imposto sobre serviços na Constituição, $1^{a}$ edição. São Paulo: Revista dos Tribunais, 1985.

MACHADO, Brandão. Fato Gerador Complexivo - uma questão terminológica. In: Suplemento Tributário. N. 73/62. São Paulo: LTr, 1982. 
MARQUES, José Frederico. Tratado de Direito Penal. Volume I. Propedêutica penal e norma penal. Bookseller:Campinas - SP, 1997.

MAYER, Otto. Derecho Administrativo Alemán. Tomo II. Parte Especial. Poder de Policia y Poder Tributário. Depalma: Buenos Aires, 1950.

MICHELI, Gian Antonio. Opere Minori di Diritto Tributario. Volume Secondo. Teoria Generale e Sistema Impositivo. Milano - Dott. A., Giuffrè Editore - 1982.

MIRANDA, Pontes de. Tratado de Direito Privado. Tomo I. $2^{\text {a }}$ Edição. Campinas-SP: Bookseller. Editora Ltda., 2000.

MYRBACH-RHEINFELD, Franz von. Précis de Droit Financier. Traductión Française par É. Bouché-Leclercq. Paris: V. Giard \& Briere, 1910.

NOGUEIRA, Ruy Barbosa. O Fato Gerador do Imposto. In: Debates Tributários. Ruy Barbosa Nogueira e Colegas. São Paulo: Resenha Tributária - Instituto Brasileiro de Direito Tributário, 1975.

OLIVEIRA, João Martins. Direito Fiscal (Estudos doutrinários e anotações ao decreto-lei n.960, de 17 de dezembro de 1938). Rio de Janeiro: Livraria Jacinto, 1943.

PESSOA, Epitácio. Pareceres Jurídicos. Tomo I. Rio de Janeiro: INL, 1959.

PINTO, Bilac. "Isenção Fiscal - Fato Gerador do Imposto - Isenções Pessoais e Reais Realidade Econômica contra a Forma Jurídica - Evasão Fiscal”. In: Estudos de Direito Público. Forense: Rio de Janeiro, 1953.

PUGLIÈSE, Mario. Instituciones de Derecho Financiero. Derecho Tributário. México: Fondo de Cultura Econômica, 1939.

Reichsabgabenordnung, Steueranpassungsgesetz. Herausgegeben im Reichsfinanzministerium. Berlin: 1941.

SCHOUERI, Luís Eduardo. O Fato Gerador da Obrigação Tributária. In: Direito Tributário. I. Homenagem a Alcides Jorge Costa. São Paulo: Quartier Latin, 2003.

SCHOUERI, Luís Eduardo. Direito Tributário. $1^{\mathrm{a}}$ Ed. São Paulo: 2011.

SELIGMAN, Edwin R. A. Essais sur L'Impôt. Traductión française d'après de $1^{\prime} 8^{\circ}$ edictión américaine par Louis Suret. Tome Second. Paris: V. Girard \& E.Brière, 1914.

SOUSA, Rubens Gomes de. A Coisa Julgada no Direito Tributário. In: Revista de Direito Administrativo. Volume V. Julho- 1946.

SOUSA, Rubens Gomes de. O Fato Gerador no Imposto de Renda. In: Revista de Direito Administrativo. Vol. XII. Abril-Junho. São Paulo: FGV, 1948.

SOUSA, Rubens Gomes De. Introdução ao Direito Tributário. Parte Especial. 1948.

SOUSA, Rubens Gomes de. Estudos de Direito Tributário. São Paulo: Saraiva, 1950. 
SOUSA, Rubens Gomes de. Relatório. In: "Trabalhos da Comissão Especial do Código Tributário Nacional”, Rio de Janeiro, 1954, volume mandado publicar pelo Ministério da Fazenda.

SOUSA, Rubens Gomes de. Compêndio de Legislação Tributária. Edição Póstuma. São Paulo: Resenha Tributária - IBET, 1975.

TESORO, Giorgio. Principii di Diritto Tributario. Bari: Dott. Luigi Macri Editore, 1938.

TORRES, Ricardo Lobo. Curso de Direito Financeiro e Tributário. Rio de Janeiro: Renovar, 2013.

TROTABAS, Louis. COTTERET, J.M. Droit Fiscal $2^{\circ}$ Editión. Paris: Dalloz, 1975.

WAGNER, Adolph. Traité de La Science dês Finances. Théorie de L' Imposition. Théorie dês Taxes ET Théorie Génerale dês Impots. Traduction: Jules Ronjat. Paris: V.Giard \& Brière, 1909.

VANONI, Ezio. Opere Giuridiche. Elementi di Diritto Tributario. Altri Saggi di Diritto Finanziario. Milano: LAEL - Dott Giufrè, 1962.

VEIGA, Dídimo Agapito da. Ensaios de Sciencia das Finanças e de Economia Publica. Rio de Janeiro: Jacintho Ribeiro dos Santos, 1927.

VIEIRA, José Roberto. A regra-matriz de incidência do IPI - texto e contexto. $1^{\mathrm{a}}$. Edição, Curitiba: Juruá, 1993.

VILANOVA, Lourival. As Estruturas Lógicas e o Sistema de Direito Positivo. São Paulo: Max Limonad, 1977.

VILANOVA, Lourival. Lógica Jurídica. São Paulo: José Bushatsky, 1976.

VILLEGAS, Héctor. Curso de Direito Tributário. São Paulo: Rt, 1980.

ZILVETI, Fernando Aurélio. Obrigação Tributária, Fato Gerador e Tipo. São Paulo: Quartier Latin, 2009.

Trabalho enviado em 31 de dezembro de 2018

Aceito em 06 de fevereiro de 2020 